\title{
ECONOMIC DEVELOPMENT AND POLITICAL TRANSFORMATION
}

\section{A Comparative Analysis of the United States, Russia, Nicaragua, and Iran}

MISAGH PARSA

Although conflicts characterize all social orders, their nature and outcome vary widely. In some social structures conflicts may be depoliticized and channeled toward individuals; in others conflict may have reformist or revolutionary consequences. Contrary to Marx's prediction, twentieth-century revolutions have not occurred in core capitalist countries. While these societies have experienced varying degrees of social reforms, it has been Third World societies that have undergone revolutionary upheavals. To some extent reforms in the core and revolutions in the periphery are interrelated, because they are parts of a single world system. On the one hand, economic exploitation of the periphery by core countries makes possible a higher standard of living, social reforms, and a reduction of internal conflicts. On the other hand, foreign domination and extraction of resources from countries in the periphery undermine local attempts at industrialization, thus generating revolutionary conflicts. To analyze the relationship between social conflict and political development, an understanding of the location of different societies within the world system is necessary. The world system only sets the stage; it does not determine the action. By focusing on social structure, rather than the world system, we can better analyze social conflicts and their possible outcome - inaction, repression, reform, or revolution.

In an important book, States and Social Revolutions, Theda Skocpol proposes to develop a structural theory of revolution, arguing that "the key to successful analysis lies in a focus on state organizations and their relations both to international environments and to domestic classes and economic conditions."' Specifically, Skocpol views international pressures such as wars or upper-class resistance to state reform as central factors leading to the 
collapse of the administrative-military apparatus, which in turn pave the way for social revolution. ${ }^{2}$ Furthermore, she argues that prior weakening or collapse of military-administrative apparatus is necessary before mass revolutionary action can emerge. ${ }^{3}$

Applied to contemporary Third World revolutions, Skocpol's analysis suffers from two problems. The first concerns the collapse of the militaryadministrative apparatus. Obviously, social revolutions involve the collapse of the military-administrative apparatus. However, the revolutionary experiences of Third World countries reveal that neither of Skocpol's conditions need exist for revolution to occur. Strong, autonomous class coalitions have brought down Third World governments and states in the absence of prior weakening or collapse of military apparatus. The collapse of the Cuban army at the end of 1958 was due neither to defeat in external war nor wholesale upper-class defection. Popular uprising, rather than defeat in war, was responsible for revolution in Iran and Nicaragua. And in both cases, the upper-class beneficiaries of the prerevolutionary policies remained loyal until the end.

The second troubling feature of Skocpol's analysis revoives around the upper-class resistance to state reform. The split between the state and the upper class, she claims, is a main condition for revolution. In relation to contemporary Third World societies one cannot really speak of a homogeneous upper class, because these societies are undergoing large-scale social transformations. In these societies, at least two segments within the upper class can be identified. One segment, highly dependent upon the state for its privileged position as well as economic and political resources, supports state policies even in revolutionary situations. Another segment, ignored and sometimes adversely affected by state policies, may oppose the government. Within this latter faction, some may be members of the traditional agrarian upper class, often adversely affected by industrialization. Others may belong to ind ustrial-commercial factions unable to obtain state favors and subsidies. Both groups may oppose state policies but their intention is more often to bring about social reforms - whether progressive or reactionary - rather than revolution. Nonetheless, because of small size and organizational weakness the contribution of dissident segments of the upper class to revolutionary politics is relatively insignificant.

Although Skocpol has broken new ground in her studies of social revolution and should be lauded, her work suffers from a lack of attention to proper structural features of social conflict. In the next section, I will present an alternative structural theory of social conflict and its possible outcome. 


\section{An Alternative Theoretical Model}

A theory of revolution must not only specify the circumstances under which fundamental change occurs, but must also predict alternative possibilities in the absence of revolution. Social revolution is but one outcome of social conflict and analysts must specify the situations that generate other results. Under what conditions do human beings join together to bring partial or fundamental changes? Alternatively, at what point do aggrieved groups grant inevitability to their suffering? When do they end up blaming themselves or other victims for their suffering?

Collective action results from pursuit of common interest by adversely affected groups. Historically, it has often taken place as a response to violations of established rights and interests, but collective action is by no means automatic. For collective action to take place, three conditions must be met: 1) victimized groups must clearly identify a concrete social or human entity responsible for their suffering; 2) their efforts to find alternative means of redressing grievances must be blocked; 3) the aggrieved must have solidarity structures capable of mobilizing their resources.

Social structure is a central factor influencing the likelihood of collective action, its targets, and consequently its outcome. In the following discussion, I will analyze two important structural factors: first, the link between political-economic structure; and second, the level of solidarity and consolidation among adversely affected groups. Table 1 presents a schematic view of the relationship among levels of political-economic integration, levels of consolidation of adversely affected groups, and their possible forms of conflict.

By levels of political-economic integration, I mean the extent to which the state, rather than market forces, determines the forms and nature of allocation and accumulation of capital. Measures of state intervention include:

\section{TABLE I}

Levels of Political-Economıc Intergration

\begin{tabular}{lll}
\hline & $\begin{array}{l}\text { Low political-economic } \\
\text { integration }\end{array}$ & $\begin{array}{l}\text { High political-economic } \\
\text { integration }\end{array}$ \\
\hline $\begin{array}{l}\text { Low } \\
\text { consolidation }\end{array}$ & Segmented class conflict & $\begin{array}{l}\text { Segmented conflict against the } \\
\text { state }\end{array}$ \\
\hline $\begin{array}{l}\text { High } \\
\text { consolidation }\end{array}$ & $\begin{array}{l}\text { Popular struggles against } \\
\text { capital }\end{array}$ & $\begin{array}{l}\text { Popular struggles to seize state } \\
\text { power }\end{array}$ \\
\hline
\end{tabular}


degree of ownership and investment in key sectors of the economy; amount of control over financial resources and their allocation to a small circle of elites and entrepreneurs; extent to which policies such as limited licensing and quotas are used to encourage rapid accumulation; finally, frequency and intensity of repression to extract surplus and subordinate the working classes. Consolidation refers to the extent of social cohesion. By levels of consolidation, I refer to the proportion of population that is both disadvantaged and organized in a bloc. Thus, a high level of consolidation implies the formation of coalitions. Although these variables may be applied to different types of social orders, the theory developed here can best be used to explain social conflicts in capitalist societies.

I shall argue that segmented class conflict is likely when both the level of political integration and consolidation are low. Under such conditions, suffering caused by the social order is most often experienced as an individual problem. Groups with strong internal solidarity may turn to collective action for economic gain. Groups with weak solidarity and few resources are more likely to direct their suffering inward or against other victims. In either case, the target of attack is deflected from the political structure, which consequently remains intact. In contrast, segmented conflict directed against the state occurs where there is a high degree of political-economic integration and a low level of consolidation. Because these conflicts are segmented, they can be suppressed or rendered ineffective. Reformist conflicts may result from a high level of consolidation in combination with a low level of integration. Under such conditions, issues of conflict tend to remain restricted to the civil society, thus increasing the likelihood that political structures will remain unchallenged. Although the state may be drawn into class conflict, it may not be the target of attack. Finally, high levels of consolidation along with a high degree of political-economic integration increase the likelihood of revolutionary conflicts. State intervention in capital accumulation politicizes economic issues, making the state vulnerable to attack. If the state pursues polarizing strategies, it will be attacked by adversely affected classes and groups that have consolidated their forces to seize state power.

To clarify the logic of this theory, the relationship between various forms of political-economic structure will be presented along with their implications for the likelihood of collective action. Secondly, the effect of solidarity structures on collective action will be analyzed. The article will conclude with some illustrations. 


\section{Social Structure and the Transparency of the Social Origins of Injustice}

Human suffering and pain by themselves do not generate collective action to transform society. One reason may be that victimized collectivities fail to view the causes of their suffering as social (or human) and consequently amenable to change. As Moore has put it: "It is not the objective suffering that is the main cause of moral anger; it is the apparent social cause. ${ }^{4}$ To perceive the causes as human is a necessary first step towards doing something about human misery and injustice." Blaming fate, the gods, other victims, or oneself will inhibit the development of a sense of injustice and thus impede collective action, even in the face of extreme misery.

Thus, disadvantaged groups must first identify a concrete social cause responsible for their suffering in order to attack it collectively. The target of such action varies widely. When directed against specific targets in the private sphere such as landlords and merchants, the results may be land reform or changes in commodity prices. However, when the state apparatus comes under attack as the source of injustice and suffering, the entire social structure may experience revolutionary transformation.

The target of collective action and consequently the nature of social conflict is largely determined by social structure. Whether a society will experience segmented conflict, reform, or revolution depends on the character of that social order. Different social structures may obscure or make transparent the connection between the suffering of victimized groups and the human or social causes of that suffering. All else remaining equal, economies oriented predominantly toward market systems tend to generate the least likelihood of revolutionary collective action. Social and economic conflicts deriving from the operation of the market forces cannot be easily articulated into political issues because of the abstract, depoliticized nature of economic transactions. In market economies, buyers and sellers of all commodities including human labor power are considered legally free and equal and, as such, enter "voluntarily" into contracts of their own choosing. For such economic actors, the market is a set of conditions within which they must work, and that, because of its abstract nature, cannot be attacked or overthrown. Moreover, that the market occasionally causes misfortune for certain capitalists adds to the illusion that the market system itself is impartial. Adversely affected groups and individuals may end up blaming themselves for their suffering. Consequently, the abstract and depoliticized nature of market systems obscures the social origins of human suffering and injustice, thus reducing the likelihood of collection action. 
Secondly, for revolutionary situations to arise, the whole state apparatus must be called into question. Where the economic system is managed and directed by a "self-regulating" market rather than the state, the likelihood of revolutionary challenge is sharply reduced. In such social structures, the state reproduces the external conditions of production, thereby maintaining the system as a whole without directly intervening in the economic sphere. The state can then claim to stand above and beyond all social classes, serving no particular interest but that of the nation. As a consequence, all social strata can be given formal representation in the political arena. Formal democracy in turn creates an illusion of equal political power among all social classes. Once the state evokes an image of neutrality, it can serve as an integrative rather than a divisive force, thereby avoiding attack and threat of revolutionary challenge.

Of course, social conflicts do emerge in market economies. These conflicts, however, tend to remain restricted either to the economic sphere or, at best, to the civil society. Such conflicts are unlikely to evolve into ideological conflicts and struggles. Thus, these conflicts may generate reform movements rather than radical social transformation.

In contrast, capitalist states that directly intervene in the process of capital allocation and accumulation tend to generate conditions leading to revolutionary collective action. State intervention undermines the "invisible hand" of the market, thereby politicizing the economy. In addition, such a state may be unable to sustain its claim of serving the national interest; it may instead become enmeshed in a continual round of contradictions: simultaneously representing the general societal interest as well as particular dominant-class interests and capital accumulation. Thus, the interventionist state increases the likelihood of becoming the target of attack.

The interaction between state and economy has a profound impact upon political consciousness and the intensity of class struggle. In the contemporary capitalist world, no true market economy exists, because states intervene in varying degrees in their economies, influencing capital allocation and accumulation. In broad outline, at least two types of intervention exist: 1) the state may intervene in the economy in a limited extent in order to "defend" it against recurrent crises such as recessions and depressions; 2) the state may extensively intervene in the economy to promote accumulation and growth by controlling resource allocation. This is an offensive intervention. The classification refers to ideal types and should not be viewed as static structures because social, economic, and political conditions always affect the nature of the relationship between the state and the economy. 
The first type of social structure approximates the conditions that already exist in most Western societies. The crisis of the 1930s generated political processes that led to a restructuring of economic systems in the West, from "laissez faire" to Keynesian demand-management and social-welfare policies designed to stabilize the macro-economy and enhance the economic security of firms and individuals. ${ }^{5}$ Subsequent state policies mostly consisted of attempts to maintain full employment, control inflation, and provide unemployment or accident insurance, and welfare programs for the underclass, as well as assisting ailing industries.

In most Western states, such intervention was defensive and limited to periods when market mechanisms actually failed. The state did not assume primary responsibility for capital allocation and accumulation. Labor legislation and fiscal-monetary policy only influenced the condition of accumulation. Perhaps more importantly, many state activities, such as welfare and social security, were redistributive rather than accumulative. Hence, the market mechanism predominantly determined the normal operations of the economy.

Following World War II, some European states, in response to international competition and working-class struggles, intervened even further in the economy. Inefficient, uncompetitive industries were nationalized as a result of pressures from workers, while capitalist demands led to broad, long-term economic planning to balance payment deficits and prevent declining growth rates. Such state intervention has resulted in increasing politicization of economic conflicts. In those countries where state intervention is higher, the level of politicization also seems to be higher and the state is necessarily drawn into social and economic conflicts.

Where leftist parties, socialists and social democrats, have come to power in Europe, state intervention in capital allocation and accumulation has been further expanded. Greater intervention has inevitably politicized social and economic conflicts, but these policies have not polarized society against the state because these governments have also introduced egalitarian reforms that favor the working class, rather than a small minority of elites. Consequently, state intervention has not generated the revolutionary crisis so characteristic of the Third World.

States in Third World countries have played an active role in the allocation and accumulation of capital. For complex social and historical reasons, partly rooted in the colonial experience, a strong commercial-industrial class did not develop in these societies. Confronted with powerful, international 
competition and rising costs of international capital in the twentieth century, the enterpreneurial class remained weak in Third World nations. As a consequence, Third World states have become highly interventionist, initiating industrial development and providing favorable conditions for the rise of an industrial class.

The form and nature of state intervention varies among Third World countries, but most of them have pursued many of the following strategies. Many states invest extensively in heavy industries, own and control vast economic resources such as banking, financial institutions, and crucial sources of raw material. The state also enters into joint ventures with private businesses and multinational corporations. In some countries, state investment accounts for as much as 60 percent of the national investment.

In addition, to prevent market misallocations and waste of resources, many Third World states practice economic planning. They encourage industrial development through policies such as allocation of state funds and capital at subsidized interest rates, credit rationing, quotas, limited licensing, tax concessions, wage-price controls, high tariff walls, and overvalued foreign exchange rates in favor of the industrial sector.

Although relatively successful in general economic terms, these policies have proved detrimental to various social classes and interests in many Third World countries. In many countries, resources, credit, and machinery are insufficiently allocated to the agrarian sector, resulting in the deterioration of agriculture. Overvalued currency, designed to facilitate the purchase of capital goods and machinery, reduces the value of agricultural exports. Food-pricing policies combined with government-subsidized food imports undermine agricultural producers. Even where states have moved to improve the agrarian sector, interventions have tended to be on the side of large, resourceful producers at the expense of small cultivators. These policies have widened income disparities in rural areas as well as the income gap between rural and urban sectors, resulting in rapid urbanization. Government emphasis in most Third World countries on capital-intensive industry has not helped absorb the expanding labor force. The presence of a large reserve army, along with government repression of the working class, has increased the capacity of wealth holders to augment their capital, and thereby fostered class polarization. Nor have state policies, such as capital allocation and price controls, served small and medium-size firms. Limited licensing, quotas, and tariff walls have encouraged growth of inefficient monopolies at the expense of small businesses and consumers. Finally, the need for rapid accumulation often impelled the state and the private sector to build on the best and invest 
in relatively developed regions. Such policies have widened the gap between regions, adversely affecting ethnic and racial minorities residing in less developed areas. The overall result of such policies has been a rise in wealth and income disparities, all in the interest of a tiny upper class often tied to multinational corporations.

This development has significant political consequences. In the first place, the high level of integration of political and economic institutions in developing capitalist societies has undermined the "invisible hand," politicizing capital allocation and accumulation. With the politicization of the market, victimized collectivities can more readily identify the state, rather than an abstract invisible market, as the source of their suffering. A second result is the polarization of society. Once the state enters into a direct and visible alliance with major capitalists, it can no longer claim to symbolize society and the "national interest," for its particular interests become too conspicuous.

The state's development policies in Third World countries often lead to the exclusion of most of society including the national bourgeoisie, the traditional middle class, the working class, and the peasantry. As a result, social support for the state is eroded, leaving it vulnerable to attack. In sum, revolutionary collective action, repression, and political instability in developing societies can be attributed in large part to the integration of political and economic institutions.

Thus far, I have analyzed the relationship between social structure and the likelihood and nature of collective action, indicating how certain social structures are more vulnerable to collective action and revolution than others. The following section will focus on the capacity of social groups to engage in collective action and effect change.

\section{Solidarity Structures, Consolidation, and Collective Action}

As the above discussion demonstrates, institutional integration and the transparency of the origins of injustice provide the motives and targets of collective action. However, this does not tell us whether or not collective action will actually take place. To be able to act upon their condition of oppression, victimized classes or collectivities need to develop solidarity structures to mobilize their resources, provide hope that their situation can be changed, and overcome the sense of inevitability of suffering and injustice. Hence, collective action requires: 1) strong solidarity structures, 2) an effective network for communication and resource mobilization, and 3) some form of coalition with other collectivities to consolidate their forces to 
counter the power of their adversaries. Solidarity theorists such as Gamson, Tilly, and Zald maintain that social solidarity, or the integration of individuals into community life, facilitates the mobilization process by providing a common set of values and interests within the community, a communication network, and an authority structure providing leadership to minimize factionalism. The greater these solidarity structures, the greater the community's capacity to claim resources from individual members while at the same time reducing exit and disloyalty.

The social structure influences social solidarity and the capacity of different groups and classes to mobilize for collective action. In general, more collective cooperation in production and distribution leads to greater group cohesion. Stratification also influences the degree of solidarity. The greater the stratification within the victimized group, the more difficulties they will have in mobilizing due to low levels of solidarity or cohesion. In contrast, low levels of stratification create fewer obstacles to mobilization.

Finally, relations between aggrieved groups and their adversaries must be considered. Clearly, conditions that give rise to collective action are characterized by a higher degree of polarization. However, polarization may be restricted by a high degree of vertical cohesion between victims and their oppressors, in combination with a high degree of dependency of the former on the latter. If victimized groups or classes are not capable of severing their ties to their victimizers, no collective action can take place.

A functionalist approach would emphasize the significance of shared values, beliefs, and ideologies as sources of stability that reduce the propensity to challenge the social order through collective action. It is true that ideologies are used to legitimize existing social relations and thereby secure the submission of the subordinate social classes. Ideologies tend to emphasize the relative superiority of the dominant classes and their greater contribution to societal functioning, survival, and progress. In addition, they usually deny structural conflict by emphasizing harmony and order through the promotion of "higher values" such as race, religion, or nationality. Finally, ideologies convey a sense of naturalness and inevitability of the existing social order.

Functional theory, however, can neither explain the origins of social values nor the fact of their change and transformation. They invoke social inertia but give no explanation for it, as though it were descended from heaven. A wealth of sociological and historical evidence exists to illustrate how certain specific social principles gain hegemony and reinforce social stability. Barrington Moore put the point brilliantly: 
The assumption of social inertia, that cultural and social continuity do not require explanation. obliterates the fact that both have to be recreated anew in each generation, often with great pain and suffering. To maintain and transmit a value system, human beings are punched, bullied, sent to jail, thrown into concentration camps, cajoled, bribed, made into heroes, encouraged to read newspapers, stood up agaınst a wall and shot, and sometımes even taught sociology. To speak of cultural inertia is to overlook the concrete interests and privileges that are served by indoctrination, education, and the entire complicated process of transmitting culture from one generation to the next ${ }^{n}$

Indeed, this complex process is by no means consensual. Force and violence have played decisive roles in the development of human civilization. Under repressive situations, victims of social processes find themselves incapable of resisting their adversaries not because they are unable to conceive of alternatives, but because of the suffering imposed by repression. In fact, the persistence of repression indicates that alternative possibilities exist, at least for some segments of the population.

Repressive strategies diffuse whatever anger victims might have developed against their oppressors, thus reducing the likelihood of collective action. Unable to change their circumstances, some victimized and powerless groups abandon their struggle. Others may even concede legitimacy to an order they are powerless to alter, fearing perhaps that otherwise the suffering might become intolerable.? Still other victims may end up identifying with the oppressors, repressing their outrage and humiliation. In this case, hatred may dissipate and become transformed into submission or internalized as feelings of inferiority. As long as aggression is directed inward or fateward, that is, toward God and religious rituals, it poses little threat to the extant social order.

If the preceding arguments are correct, a correlation can be said to exist between the level of solidarity within collectivities, and their capacity to recognize their condition as one of oppression. The greater their level of solidarity, the more the capacity they will have for identifying the sources of suffering, and the need for redress. Without strong solidarity structures, human beings may be unable to mobilize to overcome the fragmentation of social life and break away from the established social order. Instead, they may try to repress the fact of suffering caused by an unjust social structure or are persuaded to accept the blame for their own misfortunes, rather than defying the prevailing social order.

In short, without coalition, fragmented collectivities may become mired in protracted conflicts and achieve little in the way of fundamental change. The greater the level of consolidation among the disadvantaged groups, the greater the probability they will eventually obtain power. 
The likelihood of consolidation increases during economic crises when alternative strategies for living and action become limited. Crises disrupt modern urban living conditions, challenging established rights and ways of life, and generating or deepening divisions within the dominant classes. Crisis situations do not, however, automatically produce collective action; they merely set the stage. Lacking acceptable, non-violent options, a disadvantaged group must develop sufficient solidarity structures to mobilize resources and to act collectively. This class, if strong enough, may be able to draw other adversely affected groups into a coalition.

Western societies are not generally vulnerable to consolidation. In the first place, industrial societies are characterized by both a high level of economic surplus and resilience. Secondly, they are highly differentiated, with the result that separate social classes tend to experience economic crisis somewhat differently, thus reducing the likelihood of consolidation.

In contrast, disaffected groups in Third World societies are much more prone toward consolidation of forces. These societies are vulnerable to frequent economic crisis for several reasons. To begin, they lack resilience because of a low level of accumulation. In addition, because these societies are so dependent on the world market, they have little defense against economic problems such as inflation, recession, and depression that beset more advanced countries. Due to their experience with colonialism, most Third World societies rely heavily on a single crop for foreign trade and are at the mercy of fluctuations in the world market. Finally, these societies are characterized by minimal social and occupational differentiation, with the result that economic crisis generates similar experiences among large blocs of the population, thereby stimulating consolidation.

To summarize the argument thus far, it has been suggested that low levels of political intervention in capital allocation and accumulation combined with a low level of consolidation, generate segmented class conflict. When state intervention is low, abstract, depoliticized market forces predominate and obscure social origins of injustice. In addition, by remaining impervious to attack or overthrow, market forces encourage inaction. Where market economy operates in conjunction with formal democracy, they create an illusion of equal political power among all social classes, with the state serving societal interests. Thus, the two factors reduce the likelihood of attacks against the state. Inevitably, conflicts will be confined to the civil society and directed against the upper class. Groups with resources and strong solidarity could be able to organize and demand economic benefits. However, these conflicts usually fall short of politicization because they are 

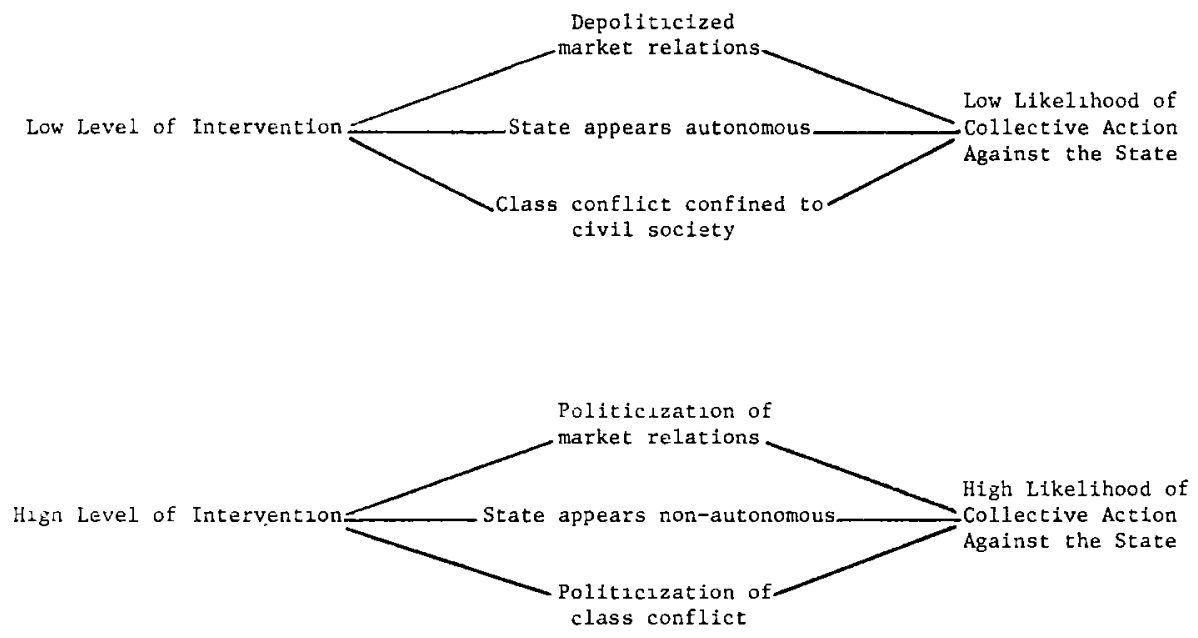

Fig. I Levels of state intervention in capital accumulation and the nature of collective action.

handled outside the political arena. Groups with few resources and weak solidarity remain inactive. Many may blame themselves or other victims for their suffering. Consequently, a combination of low state intervention and low consolidation do not tend to give rise to issues that challenge the whole social order (see Figs. 1 and 2).

Segmented conflict against the state occurs under conditions of high political-economic integration and low levels of consolidation. The state is often
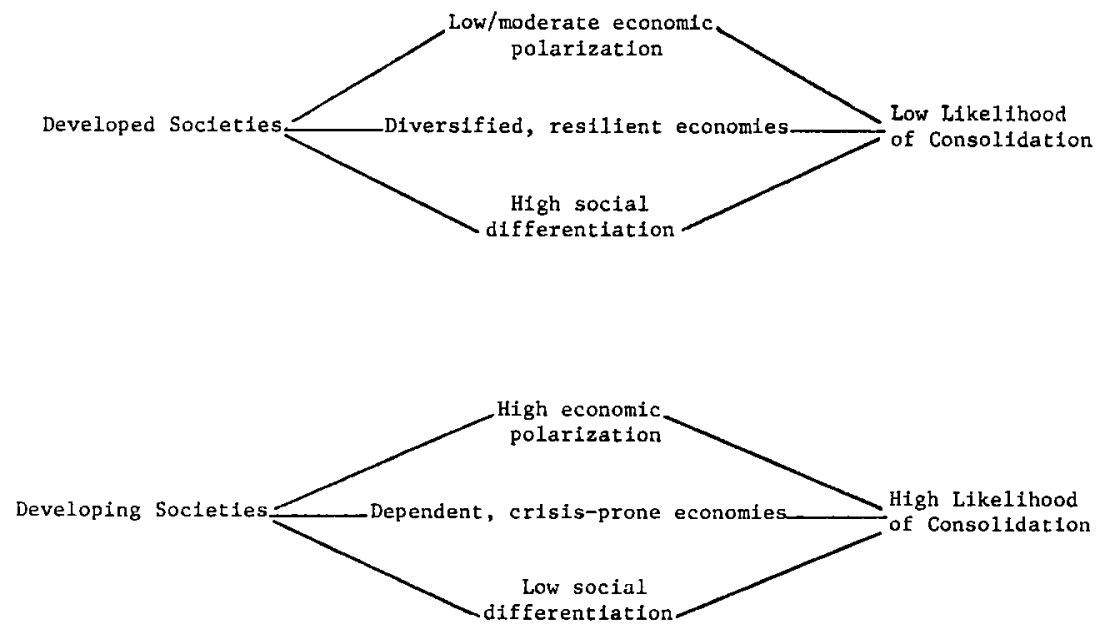

Fig. 2. Levels of development and likelıhood of consolidation of disadvantaged collectivities. 
the principal target, but the inability to mobilize and act collectively renders them vulnerable to repression. On the other hand, reformist conflict is likely when the social structure is characterized by a low level of integration and a high level of consolidation. Coalitions of the adversely affected - usually involving workers, farmers, and the petty bourgeoisie - tend to be directed against owners of large capital and particular aspects of class relations. Their struggles often draw the state into the arena of conflict, but the state does not become the target of attack. Popular struggles may demand state intervention in particular aspects of class relations. Thus, the conflicts may only affect social reforms. Finally, revolutionary conflicts are likely to emerge where a high level of consolidation coexists with a high level of state intervention in capital allocation and accumulation. State intervention politicizes accumulation, reduces the scope of the market and renders transparent the social origins of injustice. Neither market forces nor fate can be blamed for social problems or threats against established rights and interests. In addition, high state intervention, in the Third World context, often polarizes the society, and thus discredits the government's claim to serve societal interests. In the process, class conflict is politicized and directed against the state. If challengers are not strong enough, their efforts will fail and intense repression will ensue. This is the case in many Third World countries today.

Although this theory can be tested by cross-national research, an examination of single cases may better illuminate the argument. For this purpose, I have chosen the cases of the United States, Russia, Nicaragua, and Iran. The United States is characterized by a free-market economy with a low degree of state intervention in capital allocation and accumulation. In contrast, Tsarist Russia was an example of a backward European power attempting to industrialize through state policies. This pattern of development has actually been adopted in many Third World countries today including Iran and Nicaragua, the final examples to be considered here. Although they differ in economic development and potential, both experienced similar patterns of state intervention, which resulted in social revolution.

\section{The United States}

Despite undeniable social and economic problems in twentieth-century America, revolutionary conflicts have not emerged. In the past few decades, the United States has experienced one of the highest rates of unemployment among advanced industrial nations. Moreover, a considerable portion of the American population has lived in poverty throughout much of the post-war period. Not surprisingly, the United States has also been characterized by 
one of the most inegalitarian distributions of wealth and income. Yet none of these problems has generated revolutionary conditions. Even the most acute periods of economic hardship during the Great Depression led only to a series of reforms that enabled organized labor to augment its share of the national income during the post-war period. Similarly, the struggles of blacks in the 1960s resulted in reforms, the principle one being the Voting Rights Act.

Some might account for the lack of revolutionary potential in terms of the high standard of living enjoyed by the American working class in contrast to other countries where revolutionary prospects are greater. Although the standard of living in the United States is conspicuously elevated, this observation contributes little to a theory of revolution. In the first place, evidence shows that the standard of living in prerevolutionary Cuba and Iran was higher than many of their neighboring countries where revolution has not taken place. Furthermore, numerous historical examples can be cited to suggest that impoverished people do not necessarily act collectively to change their social conditions. Charles Tilly has discussed the absence of collection action during the Irish famine in the nineteenth century and in poverty-stricken southern Italy during the same period. ${ }^{8}$ Similarly, the histories of Persia, India, and China amply portray passivity in the face of extreme poverty and misery. Thus, revolutionary potential cannot be derived from the standard of living.

The theory advanced here explains the absence of revolutionary conflict in terms of low level of political and economic integration and low level of consolidation. When state intervention in capital allocation and accumulation is low, market forces become predominant. Minimal state intervention, combined with the existence of formal democracy, creates the impression that the state generally serves societal interests, rather than the interests of the upper class. As a result, the state is able to preempt challenge.

In predominantly market systems, conflicts emerge between the working class and the industrial upper class, while the state remains aloof from most disputes. Even when the level of consolidation among the dissatisfied is high, protest is not focused against the state; consequently, reformist rather than revolutionary movements may emerge. This has been the political experience in the United States since the Civil War, as a brief historical review will reveal. 
growth. Throughout the early nineteenth century, the U.S. government underwrote the building of a national infrastructure. The government also allocated capital by making land grants for railroad construction and forming semi-public corporations to finance banks, insurance, inland navigation, turnpikes. In 1816, James Madison approved bills to establish the Second Bank of the United States and set trade tariffs. James Monroe signed another tariff in 1824 as well as bills to provide for general surveys, and authorized Congress to subscribe $\$ 300,000$ to the stock of the Chesapeake and Delaware Canal Company. Tariffs were pushed even higher in 1828 by John Quincy Adams, who also made stock subscriptions for the Louisville and Portland Canal and granted lands to Illinois and Indiana to build canals. The government provided subsidies for steamships, the codfishing ind ustry, and the first magnetic telegraph line, and made interest-free advances for the manufacture of small arms. ${ }^{9}$

However, several factors operated to undermine state intervention in capital allocation and accumulation. Most important was the rise of social conflicts. As the economy matured, sectional and regional interests came into conflict over the issue of state intervention. ${ }^{10}$ Charges of favoritism, waste, mismanagement, and corruption were leveled against the government. The Civil War itself was largely the culmination of these conflicts that focused on the issue of the use of central power.

The Civil War reduced state intervention in capital allocation and accumulation. After the war, the American economy experienced its most rapid growth and industrialization with little state intervention. In rare cases, the government imposed a high tariff to protect northern industry, thereby encouraging accumulation in certain enterprises; such was the case of the tinplate industry, then in its infancy. By and large, however, the need for government intervention was reduced by rapid economic growth brought about by rising prices for American goods in the international market.

During the post-war era, economic growth was primarily achieved through a free-market economy and the initiatives of a strong capitalist class. In 1860 there were some 500,000 business firms in the United States. By the end of the nineteenth century, American technology outstripped that of Europe and the British market was invaded with American goods. "In 1860, the United States was the world's second industrial power. By 1890, the United States had attained first place, surpassing England. Between 1870 and 1920 U.S. manufacturing output rose over ten-fold, while that of England rose by less than three-fold. ${ }^{12}$ 
Toward the close of the century, however, a significant shift away from laissez faire policies was discernable among American intelligentsia. In 1885, a small band of economists proclaiming a "progressive theory of regulation" established the American Economic Association. Henry Carter Adams, professor at the University of Michigan and cofounder of the AEA, playing a leading role in the ICC, advocated the harmonious use of state power and the energies of the entrepreneur in the further development of the private economy as a whole. In 1886 Adams argued that:

\footnotetext{
the collapse of faith in the sufficiency of the philosophy of laissez faire has left the present generation without principles adequate for the guidance of public affairs. We are now passing through a period of interegnum in the authoritative control of economic and governmental principles. . principles of action we must have, for nothing is so mischievous as the attempted solution of great questions on the basis of Immediate interests alone. ${ }^{13}$
}

Economic problems and rising inequalities also led to popular demands for state intervention in the economy. Agitation by farmers and merchants was instrumental in passing the Interstate Commerce Act of 1887, which established the first federal regulatory agency. In 1890, anti-wealth, anti-big-business sentiments led to the enactment of the Sherman Antitrust Act. For the most part, however, government regulation failed to check big business, and instead, in some ways, the agencies were used effectively by businesses to coordinate their industries and serve their own interests. ${ }^{14}$ Thereafter, the government did not move forward in business regulation; although some presidents made limited attempts in that direction, the Congress impeded the changes (for example, the Congress rolled back the expansion of the administration after World War I).

Thus, the American economy was left largely unregulated, in part because of a lack of strong administrative leadership. ${ }^{15}$ Unlike European and Asian nations that retained vestiges of a bureaucratic state apparatus from preindustrial times, the United States entered the industrial era with a weakly developed administrative capacity. The main reason for the absence of government intervention in the economy was the great power of the American upper class that opposed state intervention once it was able to accumulate capital.

Working-class struggles were primarily directed against the capitalist class; however, the working class was never strong enough to challenge the power of American industrialists. Various factors combined to undermine the effectiveness of the American working class. Worker solidarity was undermined by the enfranchisement of all white males in the early nineteenth century; an influx of immigrant labor willing to work for reduced wages; the 
possibility of upward mobility; the separation between skilled and unskilled workers; as well as racial and ethnic divisions. Radical segments of the working class did attempt to mobilize American workers through organizations such as the National Labor Union (with between 100,000 to 400,000 members in 1870), the Knights of Labor (claiming 700,000 members in 1886 just prior to the Haymarket affair, which largely contributed to the organization's dissolution), and the Industrial Workers of the World. The impact of these organizations was limited. For example, in the wake of the famous Pullman strike of 1894, when labor's influence in Chicago was at its height, Labor-Populists won only about 20 percent of the potential vote $(40,000$ out of 230,000). Moreover, the success of labor was restricted to specific regions rather than the whole country. ${ }^{16}$

The final and most important factor weakening the working-class struggles was the use of repressive force by the American upper class. This class was so powerful that it was able to hire its own private army, the Pinkerton Agency, to defend itself against the working classes. By the end of the nineteenth century, active Pinkerton agents numbering some 2,000 and reserves of 30,000 totaled more than the standing army of the federal government. ${ }^{17}$ This force, supplemented by state militias, effectively kept the working class in its place.

The American upper class continued its domination into the twentieth century, competing successfully in foreign markets while resisting regulation and government interference at home. The Great Depression, however, changed the situation. The depression caused economic hardship for major segments of the American population. Perhaps the single most telling statistic is unemployment, which rose from about 1.6 million in 1929 to 4.3 million in 1930 , and 8 million in 1931 . By 1933 some 12.8 million, or a quarter of the labor force, was without employment. Another devastating consequence of the depression was the skyrocketing rate of bankruptcy, especially among small businesses. Eighty-five thousand businesses failed. To survive, firms reduced wages drastically. "In Pennsylvania, workers were paid 5 cents an hour in sawmills; 7 cents in general contracting. In Ohio, the earnings of office workers were cut by a third, those of store clerks by nearly half."18

Among those adversely affected were the American farmers. While people went without food, crops rotted in the fields in many areas. "Western ranchers, unable either to market their sheep or feed them, slit their throats and hurled their carcasses into canyons." In 1932, as much as 13 million bales of cotton could not be sold for enough profit to pay for the picking. While farm income dropped, taxes and mortgage obligations remained constant; as 
a result, thousands of farmers lost their land. ${ }^{19}$ On a single day in April 1932. one-fourth of the entire area of the state of Mississippi went to auction, leading Governor Bilbo to declare that even he was turning pink.

Perceiving their situation individualistically, most of the sufferers, especially unemployed workers, initially felt guilty and ashamed of their predicament. Blaming themselves, they failed to demand relief. However, as savings ran out and unemployment mounted, the unemployed began to recognize the social nature of the problem. Many came to believe that if there were no jobs, at least they were entitled to enough benefits to insure survival. This conclusion led many workers to stop blaming themselves and initiate collective action.

Early on, food riots were a common form of popular protest. With the appearance of organizers, especially communists, demonstrations were set up in a number of major cities. Most of the poor directed their protest against the inadequate relief system in effect and cared little about who was actually doing the organizing. Although some improvements were made in the relief system, the arrangement was inadequate and often broke down. ${ }^{20}$

Collective action by farmers, struggles by the unemployed, wage cuts, and business failures eventually culminated in Democratic victory in November 1932. Franklin D. Roosevelt swept to victory by a large margin, polling $22,880,000$ votes to Hoover's $15,750,000$. Roosevelt carried more counties than any presidential candidate had ever won before, including 282 that had never gone Democratic. With the exception of 1912, when the party was divided, no Republican candidate had ever been defeated so badly. ${ }^{21}$ In the Congress also, candidates that advocated adequate relief appropriations were elected.

By inauguration day, economic conditions were critical. The national income had declined dramatically from $\$ 380$ billion in 1929 to $\$ 50$ billion in 1932 and was still dropping, banks had closed their doors, and unemployment was rising because half of all the nation's manufacturing units had closed down. By June 1933, the end of his first "Hundred Days" in office, President Roosevelt had passed the core of the New Deal legislation. The National Industrial Recovery Act was intended to promote economic recovery through cooperation between business and government. Measures such as fixed prices were enacted to insure fair competition in business and stabilize production. To ensure the political support of labor, the NIRA gave the workers the right to organize and bargain collectively. Farmers were appeased by cheap credit, price supports, limited production, and govern- 
ment purchase of surplus crops. Most urgent was a program of emergency relief for the unemployed. Between May 1933 and June 1936, the federal government spent $\$ 3$ billion on relief alone.

This signaled a major shift in government policy. Although after World War I business had undertaken some measure of self-regulation through trade associations - in 1922, Roosevelt himself had been president of the American Construction Council - it had not invited state intervention. By 1931, some business leaders, notably Henry Harriman of the Chamber of Commerce and George Swope of General Electric, along with leaders from oil ind ustry, were calling for national economic planning. In unstable businesses like the coal and garment industries, the demand for planning came from labor leaders such as John Lewis of the United Mine Workers. Workers in competitive industries also favored regulation because of the hardships they were experiencing. ${ }^{22}$

Although designed to direct the nation's economic recovery, the National Industrial Recovery Act itself exacerbated existing conflicts and even generated new ones. In Section 7(a) of the NIRA, the industrial working class began organizing for unionization and collective bargaining. For about a century, American workers had had the right to organize, but unionization had been frustrated by employers. In Section 7(a) of the NIRA, the federal government gave its official approval to the formation of unions and collective bargaining. Once again, militants, especially communists, played a key role in unionization. In response, many industrial firms interpreted the law in a self-serving manner and organized company unions. Not surprisingly, labor resisted the imposition of company unions and struck a number of large industrial firms. Three times as many workers went out on strike after the passage of NIRA in 1933 as in the previous year. Many of the strikes culminated in violent confrontation between workers and employers; but this time employers were blocked from using court injunctions or the Pinkerton agents or the state militia to dispense strikers. Although Roosevelt's support for labor soon diminished, the working class gained a significant victory in the Wagner Act of July 1935 (which abolished child labor and established collective bargaining, a minimum wage, and maximum working hours). This victory was achieved through a combination of factors such as workers' strikes, Senator Wagner's efforts on behalf of this legislation, and some middle-class support for labor.

Despite some labor success, segments of the NIRA were gradually eliminated as segments of the business community began to attack government interference. To implement Title I, which called for the regulation of indus- 
try, General Hugh Johnson, head of the NRA, developed codes for fair competition. Partly because of a lack of administrative personnel, most of his officials were recruited from the very industries to be regulated. Major corporations were thus able to use their political position to their economic advantage. They stabilized production and granted monopolistic prices to their own firms; however, industries and small businesses that had been left out became increasingly dissatisfied with this government-business "cooperation." Eventually, as the result of a suit by a small poultry-processing company, the NIRA was declared unconstitutional, and government intervention in the economy declined.

Despite conflicts between labor and capital during the Great Depression, revolution did not occur in the United States. The failure to achieve a radical outcome might be explained by Leninist analysts as resulting from a misdirected emphasis on unionization and economic issues by the vanguard. Although this argument may be correct as far as it goes, it does not account for the Communist Party's pursuit of such a strategy. Instead I argue that the failure of revolution to emerge was rooted in the American social structure. Because of the historical differentiation between political and economic structures in the United States, working class conflicts were directed against the capitalist class, rather than the state, or both. During the depression, the state promoted the interests of the working class through Section 7(a) of the NIRA. The subsequent conflicts were directed principally toward private corporations, not the social structure as a whole. The result was reform rather than revolution.

Meanwhile, the state did become the target of small business and major industrialists left out of the closed alliance between big business and the state. State regulation of prices and production during the New Deal weakened the market forces. As the economy became politicized, segments of business increasingly attacked government intervention in the economy.

The capitalist class steadily pursued policies designed to weaken collective bargaining and depoliticize the economy. With the leftward shift of a segment of the CIO after 1935, middle-class sympathy for labor waned. By 1937, labor strikes had been put down by New Deal governors in a number of states without opposition from Roosevelt. ${ }^{23}$ American labor was weakened still further by the division between the CIO and AFL, and by World War II. A major restriction was placed upon labor during the Cold War with the passage of the Taft-Hartley Act, which some saw as a direct corporate attack. Representative Donald L. O'Toole of New York put it this way: "the Bill was written sentence by sentence, paragraph by paragraph, page by page by the 
National Association of Manufacturers." ${ }^{24}$ The Taft-Hartley Act gave courts the power to fine for alleged violations and established a sixty-day cooling off period during which strikes could not proceed. It outlawed mass picketing and secondary boycotts. Most significantly, it practically outlawed the election of communists as union officials. This last measure led the CIO to expel eleven unions in 1949, further undermining the working-class movement. The expulsion made possible the eventual merger of the AFL and CIO in 1955. In succeeding years, labor organizations limited themselves to primarily economic issues.

As we have seen, American economic transformation in the post-Civil War period was largely independent of the state, occurring instead through a free-market economy. Had government intervened directly in the process of capital allocation and accumulation, workers might have become more politicized and militant. If the NRA had survived, the state might have been attacked as an ally of big business. Indeed, shortly before the end of the NRA, some labor leaders, such as John Lewis, charged as much. With the demise of the NRA in 1935, state intervention in the industrial sector contracted. Similarly, bankers, not the state, were the primary targets of farmers' protests. Their main demand of the state was to regulate the market.

Today, the state plays little direct role in capital allocation and accumulation in the United States. It makes neither industrial investments of its own nor joint ventures with private industry. The state owns no banks that allocate capital. The government does not limit licensing in the private sector nor does it allocate quotas of foreign exchange. Direct state intervention in capital allocation and accumulation is generally low and occurs mostly for defensive purposes (e.g., farm subsidies, Chrysler bailout). Thus, its polarizing effect is not great. Finally, the state does not directly and systematically use its repressive forces against labor. Low levels of state intervention combined with the existence of formal democracy create the impression that the state generally serves societal interests. These factors together deflect attacks against the state.

In the predominantly depoliticized, market-oriented economy of the United States, the working class is excluded from exercising power, despite the existence of formal democracy. Highly differentiated and disorganized, the American working class is unable to act collectively to pursue its interests. Although organized labor in powerful industries has secured economic benefits, the vast majority of American workers remain unorganized and vulnerable to market fluctuations. Even the massive layoffs of the early $1980 \mathrm{~s}$ initiated by the American capitalists have not politicized the American working class. 
The consequence of the operation of the free-market economy has been much unnecessary suffering. Many American workers blame themselves for their social situations, feeling ashamed and guilty for what they perceive as underachievement. ${ }^{25}$ The social consequences of such a perspective were brought out in a congressional investigation of the connection between unemployment and mental illness. According to congressional testimony, a one percent increase in the unemployment rate sustained over six years was associated with 20,240 cardiovascular deaths, 920 suicides, 643 homicides, and 4,227 state mental hospital admissions. ${ }^{26}$ Clearly, much of the suffering caused by the social structure finds expression outside of the political arena. Unemployment is a modern social problem unknown in pre-capitalist societies (it would be a contradiction in terms to say that slaves or serfs were unemployed). It results from the operation of the market and is therefore difficult to attack. Once suffering is directed inward or against other victims, it is diverted from its social and political sources. As long as the political structure is not directly attacked, political dissidence, by definition, may not exist, but human suffering is real.

In summary, important social problems do not find political expression in the United States, where political-economic integration and consolidation are low. The result is largely political inaction. Organized groups can only generate segmented class conflict for securing economic interests. Even during times of high consolidation, organized social groups tend to pursue reformist social movements. Low levels of political and economic integration combined with formal democracy insulate the state from revolutionary challenge. In the decade of depression, American workers acted collectively' against their employers. Formal democracy enabled them to elect FDR, who revealed interest in some changes. The outcome was the New Deal rather than revolution.

\section{Russia}

In contrast to the United States, a number of societies have experienced massive revolutionary upheavals in the twentieth century, beginning with Russia. The Russian experience after the reforms of 1861 reveals how the interplay between political-economic integration and solidarity structures can lead to revolution.

In Russia during the nineteenth century, the highly militarized state bureaucracy exercised greater power and influence over the civil society than in Western states. The Russian landed upper class, although dominant, never achieved the immunity, autonomy, and economic strength of its Western 
counterparts. In response to the humiliating defeat of the Crimean War, (1853-1855, with England and France), the Imperial state initiated a series of modernizing reforms. The new measures included establishing a modern judicial system, universal military service, and zemstvo representative assemblies and municipal dumas with limited powers of self-government. Two additional reforms drastically changed the Russian social structure and widened state intervention in the economy while simultaneously weakening the landed upper class. The first was the abolition of serfdom in 1861, followed by a state development policy that extracted greater surplus from the agrarian sector for rapid industrialization. These policies threatened the landed upper class; but members of this class could not challenge state power because they became increasingly dependent on the state to maintain their social and economic position.

Land reform, partly initiated for purposes of modernization and partly out of fear of abolition of serfdom from below, and the state economic policies had adverse effects on major segments of the upper class. Although the Landlord Committee had some influence in implementing land reform, the reform subjected the upper class to capitalistic practices to which it could not adapt quickly. Thus, many land holders were forced to sell their estates to merchants and peasants. Between 1877 and 1905, the upper class lost nearly one-third of its land. To provide financial assistance to the hereditary nobility, the state established the Nobles' Land Bank, which loaned large sums with combined interest-and-amortization payments lower than those charged the peasantry by the state-run Peasants' Land Bank. ${ }^{27}$

Land reform also meant hardship for most of the peasants, who generally received the more unproductive land from the estate. To buy their liberty, peasants had to put up 20 percent of the value of the land. The state provided the rest, which was to be repaid in the course of 49 years at a rate of 6 percent annual interest. Many peasants could not keep up with the payments and increasingly fell into arrears, which increased from 22 percent of the total annual payments in 1875 to 119 percent by the end of the century. ${ }^{28}$

State agricultural policies added to the problems associated with land reform. With a weak commercial and industrial base, Russia's industrial development was dependent on Western Europe. To repay foreign loans and interest charges, the government needed a large surplus, which it obtained through grain exports. From 1890 until 1911, grain accounted for between 46 and 52 percent of all Russian annual exports. ${ }^{29}$ This dependence on foreign grain sales brought little benefit to landlords and cultivators, who favored free trade for low-custom duties to avoid paying high prices for imported 
manufactured goods. Favorable import policies along with improved cultivating techniques would have increased agricultural production and widened the market for the industrial sector.

Instead, state economic policies directed by Count Witte after 1890 moved to restrict peasant consumption rather than encourage production. In addition to redemption payments, peasants paid from ten to forty times more taxes than estate owners. Whereas landlords paid between 2 and 10 percent of their income to the state, peasants were assessed at more than 50 percent. Of some 208 million rubles levied in 1872, 195 million rubles came from peasants, while landlords paid a mere 13 million. Although direct taxation declined by the end of the century, it still imposed a heavy burden for the impoverished Russian peasantry. The state also levied a heavy excise tax on alcoholic beverages, a government monopoly highly consumed by the low income rural population, many of whom were alcoholic. Finally, the state indirectly taxed peasants through the sale of kerosene, tobacco - both government monopolies - matches, sugar, and imported staples such as iron, cotton, tea, and manufactured goods.

Low productivity, combined with population growth and increasingly heavy extraction of agrarian surplus resulted in a deterioration of peasant life. Per capita output declined after $1890 .{ }^{30}$ Per capita grain consumption fell by about 200 percent between 1883 and $1914 .{ }^{31}$ As the population increased, the size of the average peasant holding shrank from 13.2 desyatinas (one desyatina is 2.7 acres) in 1877 to 1.4 in 1905 . The number of cattle also declined from 37.2 per hundred persons in 1880 to 30 in 1909. Peasant nutrition, estimated in a report to Premier Count Witte to be deficient by 30 percent under normal circumstances, worsened with harsh government policies. ${ }^{32}$ Despite the increasing frequency of famines and peasant starvation, government grain exports continued. ${ }^{33}$

Russian economic development was paid for in part by the declining standard of living of the peasantry, as the state used agricultural surplus to subsidize industrial projects. The state rejected a laissez faire policy of development and instead assisted the private sector directly in rapid industrialization. To provide capital for investment, the government turned the central bank into the State Bank, which induced private banks to initiate financial operations. The State Bank cooperated closely with private banks, carefully nursing their financial operations until the collapse of the Tsarist Russia in 1917. Between 1892 and 1900, the banking system put 229.6 million rubles at the disposal of the economy. Huge state expenditures to set up government-owned industries also injected money into the economy. 
Between 1893 and 1900 , the state spent 278.3 million rubles a year on railroads, for a total of 2,226.6 million rubles. Tremendous expenditures for ports and ships during 1893 and 1894 alone involved 237.8 million rubles. New capital introduced into the Russian economy by government policies in the 1890 s totaled more than 3,000 million rubles, "a sum exceeding the yield of war indemnity which the Germans received from France in 1870." 34

The state also provided highly favorable conditions for the growth of industry. In the 1870 s and $1880 \mathrm{~s}$, Russian industrial organizations requested and were granted protective tariffs. By the end of the century, tariffs for several heavy industries had risen so high that some imports had become prohibitively expensive. In addition, the government encouraged domestic industries by excluding foreign competitors from profitable state-subsidized contracts to construct railroads and ports. As a result, Russian business enjoyed a monopoly of large construction projects and charged correspondingly high prices for their services.

Such government protectionism was deemed necessary because otherwise private businesses would not have undertaken major investments under conditions of high risk. Over time, however, state policies favoring the private sector were increasingly criticized for favoritism and squandering public money for the benefit of tycoons. In response to criticism of negligent and wasteful policies, the government eventually took over the whole railway economy.

State economic policies paid off in rapid development. Between 1890 and 1900 , Russian industry grew at an average rate of eight percent per year, and industrial production more than doubled. During the same period, the number of factories and works increased from 32,254 to 38,141 ; while output rose from 1,502.6 million to $3,438.9$ million rubles. ${ }^{35}$ In 1900 , Russia's oil production was the highest in the world. ${ }^{36}$

Despite rapid industrial growth, development affected social groups and classes unevenly. Government policies encouraged heavy industries such as iron, steel, petroleum, and machinery. Within these sectors, a small number of firms utilizing sophisticated machinery accounted for a major share of the output. In the petroleum industry, for example, less than 10 percent of the firms produced 69 percent of all petroleum products. In 1898,4 percent of all coal mines accounted for 43 percent of the total coal output. ${ }^{37}$ Crucial to the nation's industrial development, were railroads constructed by a dozen "favorite" plants owned primarily by persons close to the upper circles. Through its monopolistic practices, the state virtually subsidized this giant 
industry. Even modest estimates indicate that overpayment cost the national treasury 15 million rubles a year. ${ }^{38}$

Such policies enriched not only major Russian industrialists but their foreign counterparts as well, for fully one-third of the capital invested in Russia in the late nineteenth century was supplied by foreign firms. ${ }^{39}$ Civil servants also profited from administering state enterprises, allocating capital, licensing, imposing quotas and controls on the private sector. In contrast, small firms producing consumer goods received little of the preferential treatment extended to large enterprises. This was a result of government strategy that avoided development through light industries based upon mass-market demand.

National minorities and the urban working class suffered as a result of the state economic practices. Russian industrialization was concentrated in relatively few regions of the country and provided little benefit to most national minorities. Consequently, regional disparities widened during the period of heavy industrialization. Industrial workers labored under adverse conditions, working from twelve to seventeen hours a day. The government directly intervened in factories to prevent the formation of labor organizations. Legislation passed in 1886 extended police surveillance in factory towns to control labor. State intervention on behalf of the capitalist class proved detrimental for workers. Wages remained low in light industries that did not receive government subsidies. Employees in heavy industries fared little better; oil workers in Baku worked sixteen or seventeen hours daily for low wages. ${ }^{40}$

Toward the end of the nineteenth century, in response to worker pressure, the government promulgated legislation to modify the situation. New laws regulated conditions for hiring, abolished child labor, and outlawed payment in kind. In 1896, legislation was enacted limiting the workday to eleven hours and establishing Sunday and holidays as days of rest for all workers. However, these restrictions applied only to enterprises that employed more than twenty workers, and even then were rarely enforced. Although the government improved laws concerning industrial accidents, the predicament of workers injured on the job was largely unchanged. ${ }^{41}$ At the turn of the century, the Russian working class remained both exploited and defenseless.

With the depression of 1900, economic growth slowed and the resulting crisis (combined with repression) left the working class no alternative but rebellion. In the summer of 1903, the Baku oil workers' strike was quickly taken up in Tiflis, Batum, and other Caucasian towns. Workers walked out in 
Odessa, Kiev, and elsewhere in Russia. Equally important was the fact that strikes rapidly assumed political character.

Working-class insurrection gradually assumed nation-wide proportions and numerous Soviets were founded. Soon there were continual work stoppages. Workers participated in more than one strike, accounting for the fact that out of an industrial work force of less than two million, the number of strikers enumerated in 1905 was $2,865,145$. Roughly two-thirds of the walkouts were political in nature and were directed against the state and the large firms.

Rural areas also showed signs of rebellion. Poverty-striken peasants in some districts raided and attacked the estates of landowners in the spring of $1902.4^{42}$ Early in 1905, striking agricultural workers illegally cut timber belonging to the state and individual landlords. In August, a gathering of peasant delegates met near Moscow with a few representatives from revolutionary parties and proclaimed "the Constitutional Assembly of the All-Russian Peasants" Union" to work for the abolition of private landed property. By autumn, peasant rebellion had spread throughout the countryside. ${ }^{43}$

However, lack of leadership, of coordination of collective action, and of a clearcut program fatally weakened the movement. Most of the peasant rebellions were unplanned and sporadic. Urban workers were better organized, but poorly coordinated. Resistance by two thousand armed workers in Moscow collapsed after being fired upon by reluctant soldiers in the Moscow garrison backed by reinforcements from St. Petersburg. Although Moscow's poor backed the revolutionaries, solidarity broke down when they were forced to split into small groups to avoid the army's fire. Had workers in St. Petersburg struck and paralyzed the railroads, as occurred earlier, military reinforcements would not have arrived at all and the outcome might have been very different. Eventually, as Count Witte had calculated, a new constitution and the promise of civil liberties in October 1905 split liberal and socialist forces. The dissolution of solidarity resulted in the final defeat of the rebellious forces. By mid-June 1907, the Tsar dissolved the Second Duma along with whatever civil liberties had been gained.

During the next few years, state agricultural policies underwent some modification. Recognizing the potential danger of rural communes, the government attempted to break them up and instituted private plots. In November 1907 , the compulsory communal life of peasants was weakened by legislation giving them the right to demand their share of land from the consolidated holding. Three years later, another law made possible the dissolution of any 
commune by a majority vote of its members. These reforms, initiated by Stolupin, had little effect, as evidenced by the fact that only 22 percent of those peasants living communally chose to leave. Of these, only the more prosperous peasants actually benefitted from these changes, while the majority of peasants continued to live in traditional communes.

During this period, the Peasant's Land Bank provided capital to encourage the formation of individual farms and occasionally granted fifteen-year loans without interest or subsidies. By the end of 1915 , the bank had extended 300,000 loans averaging 100 rubles each, and 58,000 grants averaging about 22 rubles. The government also showed more interest in improving agricultural productivity by importing agricultural implements and providing technical education.

It is unclear, however, whether those who established individual farms really benefitted from the reforms. For example, protective tariffs that encouraged cotton cultivation in central Asia, were beneficial only to the small minority of producers who used modern equipment. Industrial tariffs kept the price of most manufactured products high, which proved extremely disadvantageous for the peasant population. A comparison of prices in Russia, England, Germany, France, and the United States in the last pre-war year indicates that while most foodstuffs were about one-third cheaper in Russia, most manufactured goods were priced higher than in other countries. ${ }^{44}$ Finally, the reforms may actually have concentrated land in the hands of more prosperous farmers, as some peasants and nobles lost their holdings.

The state industrial policies remained largely the same. The government continued to finance its development by taxing the population through its monopoly of goods such as alcohol, railroads, kerosene and through indirect taxes on mass consumed goods like tea, tobacco, sugar, and matches. The state borrowed heavily from abroad to finance industrial development. In 1913, Russia ranked second in the world in absolute size of its national debt. ${ }^{45}$ The state protected industries through limited licensing, quotas, tariff policies, and guarantees that encouraged investment in risky areas. State banks and private financial institutions, still dependent on the government, continued their previous emphasis on large, heavy, modern industries at the expense of small, light, traditional manufactures. ${ }^{46}$ During this period, the industrial structures created by the state were further solidified through ind ustrial concentration and formation of monopolies. ${ }^{47}$

The result of these policies was rapid economic development. Per capita GNP grew from 63 rubles in 1897 to 101.4 rubles in 1913.48 Agricultural 
income grew by 88.6 percent from 1900 to 1913. From 1911 to 1913, grain exports were 50 percent higher than from 1901-1905. Exports of butter, flax, and other agricultural products also increased. ${ }^{49}$ Industrial development was also impressive, as the total value of ind ustrial output increased 72.9 percent, from 2,839.1 million rubles in 1897 to $4,907.7$ in 1908.50 Between 1907 and 1913, annual industrial growth was about 6.25 percent.

While a tiny upper class was the main beneficiary of the government industrial policy, the Russian working class gained little. With the Stolypin "coup d'etat" of 3 June 1907, repression and persecution of workers spread, wiping out the employers' concessions made after the 1905 revolution. During the recession of 1907-1909, the nascent labor union movement fell into disarray. By the end of 1907, 25 to 30 percent of the metalworkers in the Moscow region and 36 percent in the capital were out of work. ${ }^{51}$ In the meantime, rapid economic growth expanded the Russian working class, which became concentrated due to the emphasis on heavy industry. According to Gordon:

In the concentration of production, Russia, as early as 1895 had surpassed Germany. In that year. the wage earners in Russian factories with more than 500 employees constituted 42 percent of all workers, whereas in Germany, these large establishments accounted for only 15 percent of the working population... by 1912 the workers in Russian factories with more than 500 employees were 53 percent of the whole. As late as 1925 in Germany, the establishments with 1,000 or more employees had 30 percent of all workers in factories with more than fifty hands. Russia, as early as 1912 had 43 percent in factories employıng 1,000 persons and over. .even more strikıng is the comparison with the United States. Of all employees in establishments with more than fifty hands, the workers in enterprises of five hundred hands or more were 47 percent in the United States in the year 1929. They were 61 percent in Russia in 1912.52

This great concentration inevitably enhanced the capacity of the working class to act collectively. At the same time, the bargaining power of workers increased due to economic improvement. After nearly a decade of stagnation, the Russian economy began to revive toward the end of 1909 , first in the consumer sector and later in heavy and capital goods industries. Unemployment fell, and workers' position in the labor market improved, leading them to demand redress of grievances. ${ }^{53}$ Just before the war, the government was forced under protest to liberalize and allow the formation of labor unions and Bolshevik activities.

In the five years prior to World War I, Russian workers and peasants intensified their struggles. Walkouts rose from 222 in 1910 to 3,534 in 1914, while the number of workers on strike grew from 46,623 to $1,254,441$. Strikes became increasingly political in nature. In 1914 , politically motivated strikes numbered 982,810 , the highest since $1905 .{ }^{54}$ Strikers demonstrated considerable solidarity. For example in 1912, the massacre of several hundred 
workers in the Lena gold fields of Siberia was protested by a wave of strikes across the country. In March 1914, just a few months before the war, ind ustrialists recognized the dimensions of the crisis and declared a lockout in St. Petersburg that affected some 70,000 workers. This, too, resulted in large-scale demonstrations. Rural areas were also in turmoil during this period. Between 1910 and 1914, more than 13,000 disturbances broke out among the peasantry. ${ }^{55}$

Thus, Russia entered the European conflict convulsed by politicization and polarization. During the war, the state imposed new demands for resources and manpower upon the population, especially the working classes. Extraction of resources further jeopardized the survival of an already weak state.

Shortages and rising inflation caused by the war aggravated the plight of workers and peasants. Despite wartime restrictions, walkouts and food riots persisted, although at a lower intensity throughout 1915 and 1916. Eventually, strikes spread nation-wide, and the working class banded together with the peasantry to oppose the Tsarist state. Soldiers, suffering from the hardships and defeats of the war and in sympathy with the opposition, stopped fighting for the Tsar and joined rebellious workers in Petrograd. In March 1917, Tsar Nicholas II fell, preparing the way for the Bolshevik seizure of power in October.

The government's role in accumulation progressively expanded to the point where, by 1914, the Russian state was the biggest landowner and capitalist in the world. The state controlled much of the country's financial assets, including the State Bank, Peasant's Land Bank, and the Noblemen's Bank. It also possessed vast tracts of land encompassing 60 percent of the country's forests as well as valuable mines and ore-processing plants in the Altai, the Urals, and Siberia. ${ }^{56}$ The state owned over 10 percent of the nation's industry. ${ }^{57}$ Finally, the state received direct and indirect taxes, in addition to borrowing money from abroad.

The state used its enormous capacity to pursue highly uneven development policies. Favorable credit and relief were provided only to certain members of the upper class. As the economic position of wealthy land owners weakened, they became more dependent on the state for bureaucratic jobs, emoluments, and subsidies. The landed upper class also depended politically on the state to maintain its grip over the countryside. ${ }^{58}$ Wealthy industrialists also were dependent on the state for highly favorable loans, subsidies, and protection from competition through limited licensing and quotas. Finally, the industrial upper class relied on state repression to keep the working class in place. 
State pólicies towards the peasants and workers were entirely different. As the landed upper class lost its power and influence over the countryside, the state took its place and confronted the Russian peasantry directly. The state failed to improve the condition of the vast majority of these peasants living in communes, nor did it extend to them economic subsidies handed out to the landed upper class. Instead, they were forced to carry the burden of industrialization through heavy extraction of surplus, which kept peasants impoverished. Workers in urban industries were also exploited and repressed. The Russian state rather than the market, mediated between the workers and employers. Consequently, economic issues and conflicts were rapidly politicized.

Finally, society and the state were vulnerable to general economic crisis and thereby receptive to consolidation by major social classes and groups. The Russian economy, which was highly dependent on external capital, markets, and technology, was disrupted by the war and rendered incapable of functioning. At the same time, peasant communes and workers' solidarity structures provided the resources for mobilization and collective action, leading to a consolidation of forces.

Adversely affected by several decades of state-sponsored development, the Russian working classes had both the capacity to act collectively and a clear target of attack. The narrow alliance between the state and the upper class had a negative impact upon the rest of the Russian society, thus polarizing the population. State policies were substituted for the invisible hand of the market, thus politicizing most important economic issues. Finally, the crisis generated by the war, facilitated the formation of coalitions and consolidation among major segments of Russian society, resulting in the downfall of the Tsar.

The Bolsheviks gradually merged political and economic structures to the point where the state completely assumed the allocation and accumulation of capital. As a consequence, all social and economic issues were politicized. Although total political-economic integration expanded state resources, it also set limits on the ability of the state to carry out certain policies. Forced industrialization and collectivization so polarized society that the state could preserve the social order only through massive repression. In the 1950s, terror was reduced as a result of Khrushchev's reforms, which improved the standard of living of the Soviet working class and gave workers the right to change jobs at will. Although the reforms created a semi-free labor market, they did not change the basic social structure in which the state controlled capital allocation and accumulation. This structure has led to confrontation 
whenever the state has threatened workers' established rights. In 1962, a workers' revolt in Novocherkassk against state-initiated price increases was severely repressed. Through subsequent reforms, Soviet leaders attempted to rationalize the economy, reducing reliance on central planning while increasing the role of individual enterprises in promoting efficiency and profitability in the 1960s. As a result, these "reformed" enterprises drastically reduced the number of workers, improved work organization and productivity, lowered costs, and stimulated the economic interests of the remaining workers. By placing greater emphasis on technicians, engineers, and experts, such reforms threatened the interests of lower and middle level bureaucrats. More importantly, they suddenly converted semi-skilled workers into a "reserve army" of unemployed laborers. Not surprisingly, discontented bureaucrats and workers formed an informal alliance that interrupted the reforms in the early 1970s. ${ }^{59}$ Confrontation between workers and the state prevented the Soviet leaders from pursuing policies that American capitalists carried out easily in the 1980s.

Today, the Soviet working class, prevented from participating in decision making, accepts the prevailing distribution of power as long as prices of basic necessities and major services remain low, jobs are guaranteed, and people are free to seek individual means to improve their living standards. ${ }^{60}$ Deterioration of these conditions may lead to economic polarization resulting in attacks against the state.

To reduce the likelihood of popular confrontation with the state, Soviet leaders have attempted to fragment the population. Such strategies include raising inequality within the working class by promoting closed enterprises and closed cities employing skilled labor at higher pay and providing channels of upward mobility for highly talented individuals. These measures along with the ever-present fear of repression reduce the chances of collective action. As a result, most people choose individual ways of improving their lives. Some who refuse to accept the prevailing order may resort to alcoholism, an historical Russian solution that predates the October revolution. Under these conditions, minorities who reject the social order can only generate segmented conflict that rarely succeeds in bringing change, for it can easily be repressed.

\section{Nicaragua}

The Nicaraguan revolution of 1979 occurred within a primarily agrarian structure that was undergoing some measure of state-sponsored economic development. Significant changes in the world market and international 
relations in the decades following 1950 enabled the state to take the initiative in the country's economic development. Despite some success, state activities polarized and politicized various segments of the population below the ruling class, resulting in the revolutionary struggles of 1977-1978 that culminated in the downfall of the Somoza regime in July 1979.

Following World War II, the Nicaraguan government actively began to promote economic development. The state expanded the nation's infrastructure including highways, roads, railsystems; supplied electric power; and most importantly, allocated capital for economic investment. In the 1960s the National Economic Council designed plans to reduce Nicaragua's vulnerability to fluctuations in the world market. The Planning Office encouraged agricultural diversification, and promoted industrial development within the framework of the Central American Common Market.

State economic policies generated sustained economic growth. The GDP grew at a real average rate of 5.2 percent in the $1950 \mathrm{~s}$ and 7 percent in the 1960 s. ${ }^{61}$ Although the economy experienced sharp cyclical downswings in the late 1950s and late 1960s, in general the post-war era can be characterized as the most dynamic period in Nicaragua's economic history.

The state played a central role in agricultural diversification and development. Historically, Nicaragua's economy had been based almost solely on coffee and bananas. In the 1950s, the state encouraged the production of cotton by building appropriate infrastructures, providing favorable exchange rates, tariffs, and pricing policies, all of which stimulated investment in labor-saving machinery. In 1950, Nicaragua probably had less than 500 tractors, while five years later, there were 2,500 . The state subsidized irrigation and research projects as well as the construction of storage, processing, and marketing facilities. More importantly, the state pursued a subsidized credit policy. After 1960, the Banco Nacional extended credit based on yield, which further encouraged rationalized production. ${ }^{62}$ By the mid-1950s, cotton growers were receiving two-thirds of the value of all bank credit. ${ }^{63}$ Equally significant, throughout this era, the state prevented the formation of unions among the majority of rural workers; as a result, wages were kept low and capital accumulation was rapid.

The results of these policies were impressive. In combination, they were responsible for generating the highest yields in the world for nonirrigated land, twice the level of yields in the United States. ${ }^{64}$ Cultivation land increased fivefold from 1950 to 1970 , and cotton production rose from 3,300 tons in 1950 to 125,000 in 1960 . These state policies were later extended to 
other export-oriented enterprises such as beef, sugar, bananas, and irrigated rice, which also soon prospered.

The state also promoted industrial development through a policy of importsubstitution. With the Alliance for Progress, American economic assistance more than doubled and military aid rose sevenfold. These resources enabled the Nicaraguan state to take crucial steps toward industrialization in the early 1960s. In addition to building infrastructure, the state extended favorable exchange rates, tax holidays, and subsidized credit. Through limited licensing, it eliminated business competition, thereby providing secure markets. Equally important, workers' wages were kept low through state repression, which prevented the formation of strong and autonomous labor organizations and permitted rapid accumulation of capital.

These state policies, together with increasing U.S. economic aid, generated positive results. Industrial production increased from 15.7 percent to 29 percent of GDP between 1950 and 1970. Manufacturing was the basis of this growth, and its share of GDP increased from 11.5 in 1950 to 23.7 in 1977. From 1960 to 1970 , manufacturing grew at 11.1 percent annually, a rate that was second only to Brazil in Latin America. ${ }^{65}$

However, growth was not experienced evenly. State allocation of capital was biased in favor of large, modern firms, which resulted in further concentration. For example, fewer than twenty exporters accounted for all cotton exports, with most of the trade going to five firms. Large cattle ranchers also benefitted tremendously from state policies. Twenty-seven percent of all cattle and more than half of the available pasturage was controlled by a mere 2 percent of ranchers. The same conditions prevailed in the sugar, tobacco, and banana industries.

The uneven policies had an adverse impact on small and medium-sized firms as well as the rural proletariat, many of whom were displaced. While agricultural production increased 137 percent from 1960 to 1977 , the proportion of workers engaged in agriculture declined from 58 percent to 50 percent. In 1977, 16 percent of the agrarian labor force was unemployed. ${ }^{66}$ An AID-sponsored inquiry undertaken in 1972 concluded that if action was not taken, the difference between haves and have-nots could lead to social upheavals. ${ }^{67}$ Although some reforms in state credit policy and land distribution emerged from the report, they proved too little and too late.

State intervention in industry as in agriculture, favored large, modern enterprises and led to heavy concentration. Of the 600 industrial plants employing 
five or more persons, 136 produced 72 percent of the total output in 1971, while only 28 accounted for 35 percent. In contrast, 13,000 small enterprises were able to generate only 5 percent of the country's industrial production. ${ }^{68}$ Manufacturing, too, grew unevenly in different regions. Most manufacturing originated in the Pacific region. Factories in Managua accounted for about 60 percent of total manufacturing output. More advanced infrastructure and access to financial services account for this regional development. ${ }^{69}$

The immediate result of this development was the rapid rise of inequality in wealth and income between 1960 and 1970. The upper class absorbed a growing share of the pie, while the middle and working classes received progressively less. Although no longitudinal data are available for this time period, all experts agree that the distribution of income worsened. Agrarian land was very unqually distributed with some 3.5 percent of the population owning 63.1 percent, while the bottom 51 percent of the population owned only 7.5 percent of the land. ${ }^{70}$ In the 1970 s, the bottom half of income earners received 15 percent of the national income, while the top 5 percent received 30 percent.

Government policies failed to improve the quality of life for most Nicaraguans. Nearly half of the country's housing, and up to 80 percent in rural areas, lacked indoor plumbing. Nicaragua had the highest rate of alcoholism in Central America and the highest rate of homicide in the world. "T The average Nicaraguan had a life expectancy of fifty-three years, the lowest in Central America. Infant mortality rate was the second highest in the region. Outside the cities, lack of potable water caused epidemic intestinal diseases that accounted for almost one-fifth of all deaths. Compared to other Central American countries, the Somoza government allocated the smallest share of its budget to health and education. ${ }^{72}$

Who were the principal beneficiaries of development? Three segments of the Nicaraguan bourgeoisie benefitted from government policies. The first group, the Banco Nicaraguense (BANIC), had its origins in the 1950s among old-line liberal landowners and the emerging cotton sector. The second group, the Banco de America (BANAMERICA), was tied originally to the conservative oligarchy. After the war, both invested heavily in manufacturing, commercial enterprises, real estate, and construction. The third group was the Somoza family and its closest collaborators who also made substantial investment in modern agriculture, industry, and commerce. Taking advantage of the Central American Common Market's reduction of trade barriers, the Somoza family entered into interregional commerce, fishing and fish canning, meat packing, tobacco products, shoes, and rice growing 
and processing. They also invested in domestic construction, real estate, the mass media, auto products, and automobile importation.

Although these three factions converged through various joint ventures in the 1960s and early 1970s, the Somoza group always held the upper hand. Supported by funds extracted from the state, (foreign aid) and its autonomous entities - the National Bank, the National Light and Power Company, the National Lottery, the National Social Security Institute among others the Somoza faction was better able to compete with its two rivals. Control over state power enabled the Somozas to operate illegal businesses, create legal monopolies for themselves, and demand bribes in cash or business stock in exchange for licenses, concessions, and contracts. ${ }^{73}$

In the 1970s, natural disaster along with changes in the world market disrupted the Nicaraguan development and plunged the economy into a crisis. An earthquake in 1972 cost the lives of more than 10,000 people and leveled 600 square blocks in the heart of Managua. Most government offices, the financial district, some 2,500 shops, and 45 percent of all housing in Managua could not be used.

The reconstruction of the city further expanded the role of the state in society and economy. The state had to plan and administer major projects. The state also became the vehicle for the expenditure of massive amounts of money secured through foreign loans. Increased state expenditures exerted considerable pressure on the supply of goods, especially construction materials. Shortages boosted the inflation rate from an annual average of 2.5 percent between 1965 and 1971, to 12 percent in 1973 and 14.5 percent in 1974 .

Structural changes in the world market economy also complicated Nicaragua's crisis. The devaluation of the dollar, to which the cordoba was pegged, increased the prices of Nigaraguan imports from outside the United States. Increased oil prices also pushed up the inflation rate in Nicaragua and reduced her foreign exchange, because 70 percent of Nicaragua's electric power was generated by oil. Finally, despite rising coffee prices, Nicaragua's foreign exchange declined in response to the decreasing value of cotton, sugar, and meat exports.

To finance the reconstruction after the earthquake, the state kept borrowing from international sources. By 1977 , foreign debt had reached $\$ 1$ billion, which represented a fourfold rise over six years, and the highest debt in Central America. As the World Bank and the International Development Bank began to question their policy of extending soft loans to Somoza, the 
Nicaraguan government turned to private banks in the United States. Additional funds obtained from this source worsened the problem of inflation.

By the mid-1970s, the economy was in deep crisis and state policies proved highly disadvantageous for major segments of the population. The postquake reconstruction program raised the work week from 48 to 60 hours and froze or cut wages. After 1974, the construction boom that followed the earthquake petered out, and by 1977, the GDP had dropped some 5 percent. At the same time, because of the war against the FSLN, the government doubled military expenditure, which could only be financed by printing more money (60 percent more than planned in 1978). In 1978, the government abolished tax exemption on industrial profits, thereby creating an additional $\$ 19$ million in revenues.

While most of the population suffered from the earthquake, Somoza turned the national disaster to his economic advantage. As the National Guard looted the devastated commercial sector and sold international relief materials, Somoza and his associates pocketed international funds donated for relief. AID funds were disproportionately used to construct luxury housing for National Guard officers, while the homeless poor had to live in hastily constructed wooden shacks. ${ }^{74}$ Somoza surely enriched himself as well. Upon arriving in Miami, an exiled Somoza told reporters that he was worth only $\$ 100$ million, but U.S. government sources placed the figure closer to $\$ 900$ million. ${ }^{75}$

To summarize the argument thus far, state intervention in the economy rapidly promoted economic development, especially in the agricultural sector. State allocation of capital was highly uneven: large, modern enterprises received the available resources, while small, traditional firms were deprived. State policies toward urban and rural workers were repressive and designed for rapid capital accumulation. The immediate consequence of these policies was a rise in social inequality and economic polarization. With the exception of the big bourgeoisie allied with Somoza, the development policies of the Nicaraguan government had negative consequences for all social classes. With the increasing politicization of capital allocation and accumulation, the disadvantaged could not blame themselves or the market. Consequently, the state was soon to become the target of attack.

More than two decades of economic development brought about changes that facilitated mobilization among the opposition. Urbanization rose from less than 30 percent in 1960 to about 40 percent prior to the revolution. Although repression prevented the formation of independent labor organi- 
zations, which represented about 5.5 percent of all workers in the early 1970s. industrial concentration in a few areas contributed to workers' capacity to act collectively.

Social and political organizations played an active role in mobilizing the population. In April 1972, several months before the earthquake, the Nicaraguan Catholic Church issued a pastoral letter criticizing social conditions within the country. The Church boycotted a ceremony transferring the executive office to a three-member junta. Led by Chamoro, the opposition denounced the formation of the junta, which postponed elections until 1974. In the meantime, Somoza ordered the passage of strict legislation making it a crime for the press to "defame" the government. Despite another law, making failure to vote a crime, less than half of the eligible voters participated in the elections of September 1974 in which Somoza was elected president. Again, the bishops refused to attend the inauguration and issued a joint statement criticizing the regime's economic policies. The political opposition also denounced the election as a meaningless fraud and formed a broadbased coalition, the Democratic Liberation Union (UDEL), which included the Moscow-oriented branch of the Communist Party. ${ }^{76}$

However, the opposition needed a more dynamic factor to consolidate rather than remain fragmented in small organizations, to become more effective. Toward that end, the Sandinistas played a historic role by aggravating social conflicts, seizing leadership from reformist forces, and mobilizing the masses to overthrow the regime.

By 1974, the Sandinistas had conducted unsuccessful guerrilla warfare for more than a decade. With the deepening crisis, their chance of success increased. In a brilliantly executed raid on 27 December 1974, they attacked a reception for U.S. Ambassador Turner Shelton at the mansion of Jose Maria "Chema" Castillo Quant, the Minister of Agriculture, formerly linked with Somoza's office of security. Somoza was forced to bow to guerilla demands for a $\$ 2$ million ransom, the release of a number of Sandinista prisoners including Daniel Ortega Saavedra, dissemination of guerilla communiques in La Prensa and over two TV channels and six radio stations.

The success of the daring attack encouraged all segments of society. The moderate bourgeoisie became openly critical of the regime, while the working class revealed a striking combativity. In response, Somoza declared a state of siege that lasted for thirty-three months. The resulting repression weakened the FSLN splitting it into three factions. Because discontent was mounting, however, the Carter Administration pressured Somoza to lift the 
siege, which he did on 5 September 1977. The result was a rapid spread of popular protests.

Schism remained within the opposition. In particular, non-Somoza businesses were weakly divided, lacking the organization and political experience to lead the opposition. Some pressed for democratic freedoms and minimum constitutional guarantees, while others went further and demanded the removal of Somoza. Without allying with other social groups, these factions could accomplish little, if anything.

As various political organizations within the business sector emerged only to decline, the Sandinistas sought collaboration but consistently rejected reformist tendencies, especially those encouraged by the United States and segments of the Nicaraguan businesses, as "Somocizmo sin Somoza," or Somocism without Somoza. In October 1977, twelve prominent professionals (two lawyers, two businessmen, two priests, an academic, a writer, an agronomist, an architect, a banker, and a dental surgeon) signed a political document supporting the FSLN. This public endorsement bestowed considerable respectability on the FSLN, and helped bridge the gap between the guerrillas and the non-Somoza bourgeoisie.

With the failure of business to take the lead in what was rapidly becoming a mass movement, a radical faction of the FSLN, the Tendencia Insurreccional, called for immediate armed insurrection. They believed that the working class, middle class, and church groups would support and participate in such a policy. In the early summer of 1978 , they began forming their national political organization, the United People's Movement, allying with left-wing parties and organizations.

Finally, the faction of the FSLN, the Tendecia Insureccional, took an important step that further enhanced its popularity and support. On 22 August 1978, they attacked the National Palace. This operation netted the FSLN \$ 10 million, freedom for some fifty political prisoners, and enormous media publicity. The operation also united the three Sandinista factions. From then on, they cooperated intensely with other political organizations and church groups, to unify the fragmented opposition, which consisted of workers, disaffected businesses, and the middle class. These coalitions consolidated all the major forces against the regime. Grounded in urban strikes and armed insurrection by many consolidated communities and barrios, the FSLN was able to seize power from the Somoza regime in July 1979.

In summary, the Nicaraguan state took an active role in promoting economic 
development in the 1950s and 1960s. The state intervened in capital accumulation through provision of favorable conditions, limited licensing, quotas, grants, and subsidies to a small circle of the population. Undermining the market mechanism, the state repressed the work force, politicized the accumulation, and polarized the Nicaraguan society. At the same time, the economic development did not reduce Nicaragua's dependence on the world market. Thus, Nicaragua remained highly vulnerable to economic crisis. Once the crisis erupted, disadvantaged classes attacked the state. The high level of consolidation eventually overthrew the state.

\section{Iran}

Iran's modern economic development began after the 1963 "White Revolution." Following land reform, the state provided favorable conditions for industrial growth. At the same time, rising oil revenues allowed the state to expand its own activities, becoming the most significant agent of development and industrialization. In contrast to western states, which derived their income from taxes, the Shah's state relied heavily on a single major resource: oil. Control of oil revenues gave the state a high level of economic independence, for it no longer relied on any internal sources of revenues. The result of this development was the almost total domination of the society and the economy by the capitalist state. This oil wealth was invested by the state in such a way as to have negative consequences for all major social classes leading to polarization and consolidation that overthrew the Shah.

In the post- 1963 period, the Iranian upper class was small, consisting of an upper echelon of government bureaucracy, a small group of entrepreneurs engaged in large-scale commerce, finance, and industry, and capitalist landowners. Within this bloc, the bureaucratic faction held the upper hand, but no group enjoyed a power base independent of the Shah's state. No segment of Iranian society could launch a major economic undertaking without including the royal family, if only indirectly. By and large, the majority of those who emerged as the new barons could do so through political ties with the royal court. Few of these men came from simple origins; such were people like Khayami and Sabet. After an initial success, these "self-made" men were drawn into the royal orbit, where they were ordered to start certain industrial ventures; but whatever their origins, they needed political ties with the royal court in order to gain influence and access to multinational corporations.

Despite massive accumulation, the small economically dependent industrial upper class failed to provide the monarchy with a strong base of support. State development policies could not overcome the historical weakness of 
Iranian private capital, which invested heavily in trade and real estate. In 1976 there were about fifty thousand industrial employers in Iran, representing slightly more than 1 percent of the urban work force. This sector was expanding relatively slowly and had increased by less than ten thousand since 1966. Two thirds of these employers were still located in food and textile manufacturing. Paradoxically, although the Shah's state was strong economically, it remained weak socially.

The economic strength and independence of the state did not mean that it acted impartially in its social and economic policies. In both industry and agriculture, the Shah's economic development strategy always favored the rich over the poor, the big over the small, the urban over the rural, and the skilled over the unskilled. These policies inevitably enriched a minority of the population. This demonstrated link between state policies and capital accumulation clearly revealed the class nature of the state. In the view of most Iranians, the state was determined to serve particular, rather than societal interests. These characteristics, along with specific economic development policies, led to its downfall.

To explain the political events of 1977-1979, we must analyze the economic development policies of the Shah's state; the way in which the government resources were utilized; and their subsequent impact upon various social classes and political interests. In short, we must examine the development of the oil sector.

Oil revenues, the primary state assets and indeed the basis of the whole economy in the 1970s, rose sharply from 12 percent of the GNP $(40,000$ million rials) in 1963 to over 25 percent of the GNP for 1971-1972. In 1973, it suddenly increased to $1,333,300$ million rials (nearly $\$ 18$ billion), accounting for 50 percent of the GNP. By 1978, howver, it subsided to 1,284,900 million rials, which still was almost 35 percent of the GNP. ${ }^{77}$

When the nation's financial resouces quadrupled in the last quarter of 1973 due to rising oil revenues, the Shah of Iran proclaimed free school milk, free education up to the 8th grade, and free higher education for those who wished to serve the government after graduation. Shortly afterwards, the government set aside its previous five-year plan, then less than one year old, and substituted a new set of objectives costing $\$ 69$ billion, which was twice the original cost.

During the next two years, the Iranian economy experienced a period of unprecedented boom. From March 1974 to March 1975 the government 
spent $\$ 22$ billion, a sum almost equal to the entire expenditure of the three previous years. The GNP, which had risen by 8 percent per annum in the 1960s jumped by 14.2 percent in 1972-1973, 30.3 percent in 1973-1974, and 42 percent in 1974-1975. Between 1972 and 1978 the GNP grew from $\$ 17.3$ billion to an estimated $\$ 54.6$ billion, while GNP per capita rose from $\$ 450$ in 1971 to $\$ 1,344$ in $1974 .{ }^{78}$

Iran's ind ustrial growth was one of the highest among Third World nations. Manufacturing grew at an average rate of 12.3 percent per annum for the 1963-1972 period, or almost twice as fast as the average growth of this sector in other developing countries. The rate of ind ustrial growth for the decade of 1965-1975 was 15.2 percent per annum.

However, the nation's economic development was highly uneven. A rise in urban income expanded the demand for agricultural commodities, but the agrarian sector could not keep up, and hence, benefitted little from the general economic growth. The inability of the peasantry to take advantage of the situation by stepping up production had nothing to do with the myth of "the peasant lack of response." Rather, the failure of the agrarian sector was the result of technical and institutional constraints as well as the deliberate neglect of agriculture in the government's development strategy.

Institutional constraints were rooted in the way the land reform had been carried out. To begin, half of the village families were excluded from land reform because they lacked formal sharecropping agreements with the landowners. Without land, this group was quickly transformed into a rural proletariat that lived in extreme poverty. Of those who obtained land, about 75 percent received less than the seven hectares needed for subsistence agriculture. Furthermore, most of the land that was distributed was of inferior quality and barely adequate for cultivation. This was so because the government allowed absentee landlords to select the portion of their land to be sold, and as a result, half of the best land was never redistributed. ${ }^{79}$

Absentee landlords accounted for roughly 2 percent of the landowners in 1960 and owned 55 percent of the arable land. Despite land reform, they were able to keep about half of their holdings, or some 20 million acres out of a total of 42 million acres. Most absentee landlords managed their land by means of a sharecropping system that had operated before land reform. A small minority of landlords whose holdings averaged 250 or more acres, practiced capitalist agriculture, using wage laborers, machinery, and other production inputs such as fertilizers. 
Not surprisingly, these limited improvements did not lead to any major transformation of agricultural production. From 1963 to 1974, real investment in agricultural machinery and equipment grew by 6.7 percent per annum, while total investment increased by 20 percent. During the same period, the share of agriculture in the GNP declined from 16.6 percent to 5.1 percent. ${ }^{80}$

The government's development strategy almost totally neglected the agricultural sector in favor of the industrial sector. The government implemented land reform and then left peasants to their own devices, as though the formal transfer of land titles would prove enough of an incentive to generate a miracle in agricultural productivity. Although government investment in the agrarian sector was generally low, there were some exceptions of extensive state investment in land improvement, machinery, tractors, leveling, irrigation, and fertilizers that produced satisfactory results. However, because the government extended its low interest rate credit only to big producers, most agricultural producers could not take advantage of these improvements. Rich landlords were charged less than 5 percent interest while others had to pay more than 14 percent. In the 1970s, the government finally decided to pay greater attention to the agricultural sector, but it was already too late.

With rising oil revenues and growing agricultural shortages, the government began to import and subsidize food items. Through generous subsidies, the government kept food prices down for political reasons. By 1977, the cost to Iranian farmers to produce a ton of wheat or rice was greater than the price these goods could fetch in the urban retail market. Consequently, agricultural production declined even further. The final result was tragic and lamentable. Never before had the nation been so rich nor its peasants so poor and incapable of feeding the population.

A country that prior to land reform imported very few foodstuffs now became one of the leading importers of food and agricultural products in the Middle East. By 1978, Iran's importation of food was increasing by 14 percent per annum. Experts estimated that at this rate, Iran would be importing half of its food by 1985 . Instead of at least cautioning the government against such a policy, the International Bank for Reconstruction and Development advised the government in 1974 that: "Iran should not consider itself vulnerable to fluctuations in world supplies and prices if it adopts a logical long-term import policy ... Iran can, in addition, import many agricultural products at a lower cost than it would take to produce them locally... Imports could thus serve to reduce consumer prices." 81 
The impact of these policies on agriculture was catastrophic. Deteriorating agricultural conditions led to peasant migration. From the mid-sixties, approximately a quarter of a million peasants left for the cities every year, further worsening the situation in the rural sector. With the departure of the young from the countryside, many of the traditional irrigation canals, or ghanats, dried up due to neglect or the sinking water table that resulted from uncontrolled pumping by machines owned by rich farmers, agri-business, or state-run farm cooperatives. Deprived of the younger generation, its most active and able members, agrarian society was unable to utilize its resources. In an unprecedented occurrence, agrarian land was left fallow in many parts of the country, with no one to tend it or even fight over rights of possession.

The contrast with England is instructive. In England, according to Thomas More, "sheep ate men" during the enclosure movement, whereas in Iran, the state's development policies consumed both sheep and men. In England, a process of "primitive accumulation" separated producers from their means of production, resulting in rapid economic development. The British history of expropriation, which as Marx ${ }^{82}$ put it, "was written in the annals of mankind in letters of blood and fire," contrasted sharply with the Iranian experience. The separation of producers from their means of production in Iran was carried out through the operation of market forces characterized by neither bloodshed nor development, but replete with suffering.

In the urban sector, state policies led to widening income inequality and concentration of wealth. To begin, state industrial policies favored monopolies in import-substitution. Through limited licensing and tax concessions, the state encouraged a high rate of return for the major industrialists. Profits of 30 to 50 percent were normal and gains of 100 to 200 percent were not unknown in the industrial sector. ${ }^{83}$ State banks provided low-interest credit to large, modern enterprises, ignoring small, traditional sectors. In addition, the nature of industrial development, which was capital intensive and used mostly skilled labor, created a labor aristocracy that further stratified the working class. Peasant migration swelled the ranks of the unskilled work force, intensifying the rate of urban inequality. Furthermore, the capacity of the work force to demand higher wages was effectively eliminated through government supression of independent labor organizations. At the same time, rising inflation posed a threat to all who lived on fixed incomes. Finally, the state's development policies ignored national minorities, especially the Kurds, giving rise to regional inequalities.

In a study on income distribution, the International Labor Organization concluded that in 1969-1970, the Gini Coefficient (a measure of income 
inequality) for Iran was higher than any country in the Middle East and Southeast Asia, considerably higher than Western countries, and as high or higher than Latin American countries for which data were available. Between 1959 and 1974, the expenditure share of the top 20 percent of households in urban areas increased from 52 to 56 percent while that of the bottom 40 percent declined from 14 percent to 11 percent. ${ }^{84}$ Increased oil revenues exacerbated existing inequalities.

In 1974, forty-seven of the wealthiest families controlled 85 percent of those firms with a turnover of more than 10 million rials..$^{85}$ Of these, a mere ten families owned between ten and seventy-four businesses for a total of 390 corporations. Not surprisingly, in its march toward the "Great Civilization," the royal family itself became the wealthiest in the country. They owned 137 of the 527 largest corporations and financial institutions, and controlled a major segment of the economy through their private assets. In the face of growing revolutionary pressures, the Shah belatedly issued a private "code of conduct" on 3 July 1978, barring the royal family from profiteering in business deals. Two months later, he prohibited members of the royal family from financial dealings with government agencies or firms doing business with the government. Despite the token reforms, wealth remained highly concentrated.

As oil wealth accumulated within the small circles, agriculture deteriorated, and shanty towns proliferated around major cities. Strikes were outlawed and labor leaders imprisoned. Leftists, intellectuals, and autonomy-seeking Kurds were persecuted. Thus, the Shah's regime failed to turn Iran into an industrial society, economically independent from oil and the world market. Instead, Iranian society became increasingly polarized. The ind ustrial upper class remained tiny, a mere 1.04 percent of the urban work force, but it possessed a disproportionate share of the nation's wealth. By the end of the Shah's rule, more than half the labor force was still employed in agriculture, but they accounted for less than 10 percent of the national income. What actually took place in Iran was not genuine, independent economic development, industrialization, or modernization; it was rather rapid economic growth that established some enclave industrial structures highly dependent on the world market and without adequate backward or forward linkages to the rest of the Iranian economy. A historic opportunity had been missed.

The most significant structural transformation was state penetration and politicization of the economy. At the end of this period, the state itself was the major wealthholder. Its oil accounted for more than a third of the national income. The state also owned all other sources of energy and 
minerals, all large modern industries, most of the transport, communications, banking, and insurance firms, and a sizeable number of farms and agri-business. The entire private sector seems to have received less than 20 percent of the national income. ${ }^{86}$ The state had become a visible actor, playing a central role in the economic development of the country, and the vehicle for distributing the new oil wealth.

However, the government was unable to increase its expenditures as anticipated. Continued world-wide recession, a mild European winter, and a relatively modest increase in the OPEC price of oil soon reduced oil production and revenues in Iran. By December of 1975, oil production was running twenty percent below the same period one year earlier. By 1978, oil revenues had declined from 1,333,300 rials in 1973, which represented 50 percent of the GNP, to 1,284,900 million rials, or slightly less than 35 percent of GNP. ${ }^{87}$ As a result, by mid-1976, government expenditures exceeded revenues, precipitating a fiscal crisis that forced the Iranian government to borrow funds from international sources. A shortage of funds had already led some commercial banks to turn to the international market for short-term loans. Despite financial shortfalls, commercial banks, during this period, were allowed to maintain a liberal credit policy as the money supply kept increasing at a rate of 60 percent per annum.

As early as mid-1975, the economy was out of control. Shortages led to price increases and a high rate of inflation. In order to reduce inflation, the IMF mission advised the government to reduce expenditures. Iranian officials ignored the advice, blaming instead the imported inflation for the rapid increase in prices. Soaring inflation led the government to control prices on the one hand, and increase imports by lifting the tariffs on the other. However, Iranian ports lacked facilities to handle increased imports, nor was there an adequate infrastructure to satisfy the demands of a suddenly hyperactive economy. Bottlenecks and inadequate transportation created lines of up to two hundred ships waiting an average of 160 days to unload their cargo. The result was the waste of resources and imported goods on a massive scale.

As part of its attempt to impose price controls, the government also implemented a campaign against "profiteering." In August 1975, the government rolled back prices of sixteen thousand items to their January 1974 levels. Although the profit rate was officially set at 14 percent, the inflation rate was at least twice that amount according to the government's own reports. Anyone who violated the price controls was to be arrested.

The state's policy of price controls had far-reaching consequences. The 
decision to control prices was implemented at the level of retail markets where merchants and shopkeepers operated. No control was imposed at the factory level where commodities were produced and priced; nor were controls placed on the few giant import firms. Because the profiteering campaign was unevenly enforced, few industrialists were arrested, and those who were prosecuted were outsiders, such as Elghanian, a Jewish industrialist or Habib Sabet, a member of the Baha'i community who stayed in Paris, and never returned home.

The impact on the traditional middle class, namely merchants and shopkeepers, was devastating. In the first few days of the campaign, the government arrested 7,750 shopkeepers. ${ }^{88}$ By the end of 1977 , approximately one year before the revolution, some 20,000 shopkeepers had been put into jail, according to the Ministry of the Interior. A report by Ettelaat, one of the two main daily newspapers, indicated that by the end of October 1977, over 109,800 Tehran shopkeepers out of a total of less than 200,000 had violated price controls in one way or another, and had files in court pending investigation. ${ }^{89}$ Throughout the entire country, the number of shopkeepers violating price controls had reached 220,000 by the fall of $1978 . .^{90}$ Many of the violators lost their licenses and were forced to close down. The price controls also caused bankruptcies among the traditional middle class. Thousands of small merchants and shopkeepers lost their businesses in a short time. It had become virtually impossible for the traditional middle class to do business without violating the regulations.

The "anti-profiteering" campaign generated an irreconcilable conflict with the traditional middle class leaving merchants and shopkeepers no alternative but collective action. Although the traditional middle class was in decline, it was still large and powerful, constituting almost a quarter of the work force in urban areas. More importantly, in addition to its commercial networks, many members of this class had retained their links to the mosque and supported it through religious taxes. As a consequence, the mosque became a base of support for the traditional middle class against the Shah, especially since some clerics followed Ayatollah Khomeini in opposing the Shah. By fall 1977, the traditional middle class had begun mobilizing its resources against the state. For several months, its members protested by shutting down bazaars, participating in demonstrations, and holding mourning ceremonies in mosques. After months of sustained struggles, the traditional middle class was able to draw in other adversely affected classes and groups into a coalition.

In the fall of 1978 , the new middle class and autonomy-seeking Kurds joined 
the opposition. The industrial working class, repressed politically and disaffected by rising inflation, began strikes at the same time. Their target of attack was the state. Initially, some demanded redress for economic grievances, dissolution of state-run unions and formation of independent labor organizations. As the crisis deepened, their demands became largely political. Oil workers played the most fundamental role. Heavily concentrated in a few regions, holding the key to the nation's most vital resource, they were in a unique position to influence the political process. In confrontations with the state, they struck several times and eventually refused to pump oil, calling for the overthrow of the regime.

By the end of 1978, all major segments of society including clergy, intellectuals, workers, and the middle class, had entered into an implicit coalition with the traditional middle class. The consolidated forces, led by Ayatollah Khomeini, were finally able to overthrow the monarchy in February of 1979.

To summarize, as oil revenues increased, the state became further integrated into the economy. State intervention undermined market forces, politicized capital accumulation, and polarized society. At the same time, Iranian economy became totally dependent on the oil revenues. The uneven development of the oil sector resulted in a crisis of revenue absorption, which in turn led to a high rate of inflation. The state attempted to check the rising inflation through price controls and an "antiprofiteering campaign." The imposition of price controls set the stage for a revolutionary conflict between the state and the traditional middle class leading to consolidation and dissolution of the monarchy.

\section{Conclusion}

Social structure and economic development largely influence the nature of social conflicts and political transformation. A combination of low political and economic integration and a high level of consolidation results in reformist conflicts. Low state intervention in the allocation and accumulation of capital reduces the probability that class conflict will be directed against the state. When state intervention is low, depoliticized, abstract market forces determine capital allocation and accumulation. In addition, low political and economic integration may give the state the appearance of serving societal interests rather than the interests of the upper class. This appearance of autonomy is reinforced by the institutions of formal democracy. As a consequence, class conflict is contained within civil society and deflected from the state. When consolidation is high, reformist conflicts against holders of capital may emerge. The United States experienced such 
movements in the 1930s. During the Great Depression, the state was drawn into some conflicts, but was not attacked by the working class. Today, the United States, like other advanced industrial societies, is less receptive to consolidation because of moderate levels of economic polarization, greater economic resilience, and high social differentiation. When state intervention and consolidation are low, organized groups with resources may gain economic benefits through segmented class conflict, whereas collectivities with weak solidarity and few resources remain inactive. Such is the case in the United States today.

The combination of a high level of state intervention in capital allocation and accumulation with a high level of consolidation increases the likelihood of revolutionary conflict. High state intervention in capital allocation and accumulation has crucial social consequences. First, it politicizes otherwise abstract market relations. Second, it clearly reveals the state to be allied with a small circle of upper-class entrepreneurs, thereby discrediting the state's claim to serve societal interest. As a consequence, class conflict can readily assume a political character, expanding its target to include the state. A high level of consolidation enhances the capacity of challenging groups to act collectively to resist repression and seize power. Consolidation is more likely in societies with a high level of economic polarization, highly dependent economies, and low social differentiation. Russia in 1917 and Iran and Nicaragua in 1979 are revealing examples. The Russian and Nicaraguan revolutions were carried out primarily by workers and peasants, which helps explain the socialist orientation of the new leadership. In contrast, in Iran, the revolution was largely based on the conflicts and struggles of the traditional middle class, which eventually led to the formation of the theocratic state. A combination of high state intervention and low consolidation generates segmented conflict directed against the state. Many Third World societies are experiencing such a conflict today.

To conclude, Marx's analysis focused primarily on social classes underemphasizing the significance of the state and its relation to society and economy. Skocpol's analysis, on the other hand, primarily focused on the state and the upper class, and failed to specify the proper, determining variables. If the analysis presented here is useful in specifying the conditions and forms of social conflicts, we must pay greater attention to social structural analysis, the nature of the relationship between the state, economy, social classes, and solidarity structures. 


\section{NOTES}

1. Theda Skocpol, States and Social Revolutions. A Comparative Analysts of France, Russia, and China (Cambridge: Cambridge University Press, 1979), 291.

2 Skocpol. Siater. 50

3. Theda Skocpol, "Rentier State and Shi'a Islam in the Iranian Revolution," Theory and Society' $1 /,(1982)$.

4. Barrington Moore, Jr., Injustice: The Soctal Bases of Obedience and Revolt, (New York: M. E. Sharpe, [978), 455 .

5. Thomas Weisskopf, "The Current Economic Crisıs in Historical Perspective," Socialıst Revien' 57, (May-June, 1981).

6 Barrington, Moore, Jr., Social Origins of Diciatorship and Democrac', (Boston. Beacon Press, 1966), 486.

7 Moore, Jr., Injustice, 459.

8. Charles Tilly, "Food Supply and Public Order in Modern Europe," The Formation of National States in Western Europe, (Princeton: Princeton University Press, 1975).

9. Stuart Bruchey, The Roots of American Economic Grow'th. 1607-1861, (New York' Harper and Row, 1968), 122.

10. Bruchey, Roots, 125 .

11. Philıp Bagwell and G. E. Mingay, Britain and America 1850-1939, A Study of Economic Change, (New York· Praeger Publishers, 1970), 165.

12. Bagwell and Mingay, Britain, 158.

13 Stephen Skowronek, Building a New American State. The Expansion of National Administrative Capactties 1877-1920, (Cambridge: Cambridge University Press, 1982), 132.

14 Robert Heilbroner and Aaron Singer, The Economic Transformation of America 1800 10 the Present, (New York: Harcourt Brace Jovanovic, 1977), 207-215.

15. Skowronek, Building, 121-123.

16. Mike Davis, "Why the U.S. Working Class is Different," New' Left Revlew' I23, (September-October 1980).

17. Jeremy Brecher, Strike, (San Francisco- Straight Arrow Books, 1972), 55.

18. Heilbroner, Economic, 278.

19. William E. Leuchtanburg, Franklin D. Roosevelt and the Ner Deal 1932-1940, (New York: Harper and Row, 1963), 22-25.

20. Frances Fox Piven and Richard Cloward, Poor People's Movements, Why They Succeed. How' They Fail, (New York: Vintage Books, 1977), 56-60

21. Leuchtanburg, New Deal, 17.

22. Arthur Schlesinger, Jr., The Coming of the New Deal, (Boston: Houghton Mifflin Company, 1958), 88-89.

23. Mike Davis, "The Barren Marriage of American Labour and the Democratic Party," New' Left Review 124, (November-December 1980).

24. Richard O. Boyer and Herbert M. Morais, Labor's Untold Story, (New York: United Electrical. Radio, and Machine Workers of America, 1965), 347

25. Richard Sennett and Jonathan Cobb, The Hidden Injuries of Class, (New York: Vıntage Books, 1972).

26 M. Harvey Brenner, Congressional Test Imony, (October 1976). See also Mental Illness and the Economy, (Cambridge: Harvard University Press, 1973).

27. Geroid Tanquary Robinson, Rural Russia Under the Old Regime, (New York: MacMillan Co., 1967), 131.

28. Robinson, Rural, 96.

29. George Barr Carson, Jr. "The State and Economic Development: Russia, 1890-1939," The State and Economic Gron'th, edited by Hugh G. J. Aitken, (New York: Social Science Research Council, 1959), 120-121.

30. Alexander Gerschenkron, Continuity in History and Other Essays, (Cambridge: The Belknap Press of Harvard Unıversity Press, 1968), 48.

31. Carson, Jr., "The State," 121.

32. William Henry Chamberlın, The Russian Revolution 1917-1921, (New York: MacMillan Co., 1960), 14-15.

33. Carson, Jr., "The State," 120-121.

34. Olga Crisp, Siudies in the Russian Economy Before 1914, (New York: MacMillan Press, 1976), 26.

35. Crisp, Studies, 32.

36. Alex Nove, An Economic History of the U.S.S.R., (Baltimore: Penguin Press, 1969), 13.

37. Peter I. Lyashchenko, History of the National Economy of Russia to the 1917 Revolution, (New York: MacMillan Co., 1949), 531.

38. Lyashchenko, History, 560.

39. Nove, Economtc, 18 
40 Lyashchenko. Histor!, 545-549

41. Manya Gordon, Workers Before and After Lenin, (New York: E. P. Dutton, 1941), $25-29$.

42. Chamberlin, Russian, 46.

43. Chamberlin, Russian, 49-55.

44. Robinson, Rural, 245 .

45. Carson, Jr., "The State," 131.

46. Gerschenkron, Continuitı, 57.

47. Lyashchenko, Histor, 669

48. Crisp. Studies, 112.

49. Nove, Economic, 23.

50 Lyashchenko, History, 670.

51. Victoria E. Bonnell, Roots of Rebellion, (Berkeley. Unıversity of Calıforna Press, 1983), 319.

52. Gordon, Workers, 354.

53. Bonnell, Roots, 352.

54. Leopold H. Haimson, "The Problem of Social Stability in Urban Russia, 1905-1917," Slavic Review; Vol. 23, (December, 1964).

55. Lyashchenko, History, 692-694.

56 Lyashchenko, Histor, 554

57 Crisp, Siudies, 51 .

58. Leopold H. Haimson, The Polltics of Rural Russia, 1905-1914, (Bloomington. Indiana University Press, 1979), 275.

59. Victor Zaslavsky, The Neo-Stalinist State, Class, Ethnictty, and Consciousness in Sovet Socıety, (New York: M. E. Sharpe, 1982), 48-52.

60. Zaslavsky, Neo-Stalinist, 133.

61. Julian C. Heriot, Jr, "The Economy," Nicaragua, A Country Siudy, (Department of the Army, 1982), 115.

62. Joseph J. Brooks, "The Impact of U.S. Cotton Policy on Economic Development: The Cases of El Salvador and Nicaragua," Public and International Affairs, Vol. 5, No. 9. (Spring, 1967) 194.

63. Jaime Biderman, "The Development of Capitalism in Nicaragua: A Political Economic History," Latın Amencan Perspectives, Vol. 10, No. 7. (Winter, 1983)

64. Brooks, "Impact," 208.

65. Heriot, Jr., "The Economy," 132.

66 John Booth, The End and the Beginning: The Nicaraguan Revoluton. (Boulder, Colorado: Westriew Press, 1982), 84

67. Biderman, "Development."

68. George Black. Triumph of the People: The Sandinista Revolunon in Nicaragua, (London. Zed, 1981), 40.

69. Heriot. Jr., "The Economy," 135.

70. Joseph Collıns, What Difference Could A Revolution Make: Food and Farming in the New Nicaragua, (San Francisco: Institute for Food and Development Policy).

71. Beverly May Carl, "How Marxist is Nicaragua? A Look at the Laws," Crime and Social Justice No. 21-22, (1984).

72. Booth. The End, 85 .

73. Booth, The End, 80-81.

74. Thomas Walker, Nicaragua, The Land of Sandino, (Boulder, Colorado: Westview Press, 1981), 31-32.

75. Black, Triumph, 34.

76. Richard, L. Millett, "Historical Setting," Nicaragua, A Country' Study, (Department of the Army, 1982), 39.

77. Homa Katouzian, The Politucal Economy of Iran, (New York: New York Unıversity Press, 1980), 257

78. Fred Hallıday, "The Economic Contradiction," MERIP Reports, Vol. 8, (July-August 1978), 11.

79 Eric Hooglund, "Iran's Agricultural Inheritance," MERIP Report, Vol. 11, (September 1981), 15.

80. Thomas Walton, "Economic Development and Revolutionary Upheavals in Iran," Cambridge Journal of Economics, (1980), 281.

81. Thierry Brun and Rene Dumont, "Imperial Pretensions and Agricultural Dependence," MERIP Reports, 8, (October, 1978).

82. Karl Marx, Capital Vol. I, (New York: International Publishers, 1979), 715.

83. Nıkk Keddie, "Oil, Economıc Policy, and Social Conflict in Iran," Race and Class, Vol. 21, (Summer 1979), 13-29.

84. Walton, "Economic."

85. Fred Hallıday, Iran: Dictatorship and Development, (New York: Penguin Books, 1979), 151. 
86. Katouzian, Polnical, 370.

87 Katouzian, Political, 257.

88. Kayhan International Newspaper, (August 8, 1975).

89 ETTELAAT Newspaper. (October 27, 1977)

90 ETTELAAT, (September 26. 1978)

\section{Acknowledgments}

A number of people have provided assistance at various stages of this essay. I am very greatful to Ronald Aminzade, William Gamson, Jeffrey Paige. Ronald Suny, Thomas Weisskopf, and the Editors of Theory and Society, who read an earlier version and offered constructive suggestions. Various theoretical issues were discussed with Jeffrey Broadbent. Victor Burke, Mark Chesler, Aldon Morris, Susan Rosales Nelson, Marc Steinberg, and Mayer Zald. I appreciate their contributions. Various segments of this article were presented at the Midwestern Sociological Society, April 1985, and the American Sociological Association, August 1985. 